\title{
Sistem Informasi Pengelolaan Freelancer pada Playcubic Berbasis WEB
}

\author{
Kevin Rizky Pratama'), Arie Kusumawati ${ }^{2)}$ \\ Sistem Informasi, Fakultas Industri Kreatif Institut Teknologi dan Bisnis Kalbis \\ Jalan Pulomas Selatan Kav. 22, Jakarta 13210 \\ ${ }^{1)}$ Email: kevinrp20@gmail.com \\ ${ }^{2)}$ Email: arie.kusumawati@kalbis.ac.id
}

\begin{abstract}
Playcubic is a start-up business enganged in mass media industry. The system that Playcubic currently use is still using traditional system. The system used to have the risk of losing data and faked data. This study aims to help business including process of uploading article, invitation sharing and payroll sytem for freelancer. The system under development method is using prototype development method. The results of this study are an information system that can be used by Playcubic that have been tested with black box testing.
\end{abstract}

Keyword: freelancer, information system, playcubic, prototype, Web

\begin{abstract}
Abstrak: Playcubic merupakan perusahaan start-up yang bergerak dibidang media massa. Bisnis ini masih menggunakan sistem tradisional dalam proses bisnisnya. Sistem tersebut masih memiliki resiko seperti kehilangan data dan kecurangan data. Penelitian ini bertujuan untuk membantu proses pengelolaan freelancer pada Playcubic sehingga dapat mengurangi resiko pada Playcubic dengan cara membangun sistem informasi pengelolaan freelancer untuk mengatur kegiatan freelancer meliputi pengiriman artikel, pembagian undangan hingga perhitungan gaji. Metode pengembangan sistem yang digunakan adalah metode prototype. Hasil dari penelitian ini adalah sebuah informasi freelancer berbasis web yang dapat digunakan oleh Playcubic yang sudah melalui pengujian blackbox testing.
\end{abstract}

Kata kunci: freelancer, system informasi, playcubic, prototype, Web

\section{PENDAHULUAN}

Berkat perkembangan teknologi, saat ini seluruh kegiatan manusia tak dapat lepas dari penggunaan teknologi. Pemanfaatan teknologi informasi sudah memegang banyak peranan yang sangat penting bagi masyarakat, salah satunya adalah menjaga keberlangsungan hidup suatu organisasi. Dengan menerapkan suatu sistem informasi, data-data yang telah dikumpulkan dapat saling berhubungan dan menciptakan sebuah basis data yang akan disimpan dan dapat diakses melalui perangkat komputer. Selama teknologi informasi bertumbuh, media massa menjadi salah satu media penyampaian yang berperan besar dalam mempublikasikan teknologi terkini kepada khalayak. Begitu pula dengan teknologi yang telah membantu meningkatkan kualitas penyampaian informasi dari bentuk yang paling sederhana menjadi suatu media penyiaran yang global. Perpaduan dari kedua hal ini menciptakan hubungan kerja sama yang saling menguntungkan dari pihak satu sama lainnya. Media massa atau pers merupakan media penyampaian pesan kepada khalayak dengan menggunakan alat-alat komunikasi mekanis seperti surat kabar, film, radio dan televisi [1]. Sebagai media penyampaian publik, media massa selalu mengikuti perkembangan teknologi terkini. Dapat dilihat saat ini media massa seperti koran sudah sangat jarang untuk ditemui. Sebagai gantinya, media massa menggunakan platform website yang dapat diakses kapan saja dan dimana saja oleh para pembacanya. Hal ini tentu juga berdampak pada pola membaca masyarakat yang saat ini mengandalkan berita yang disampaikan melalui platform web.

Playcubic adalah suatu media massa yang berfokus dalam membahas teknologi dan game terkini seperti laptop dan permainan konsol. Sebagai suatu media yang membahas teknologi, Playcubic menggunakan aplikasi web sebagai media penyampaian kepada para pembaca. Berbagai berita dan artikel yang dihasilkan ditulis langsung oleh para penulis Playcubic. Hingga saat ini, Playcubic memiliki jumlah penulis hingga mencapai 30 orang. Para penulis ini bekerja sebagai freelancer yang tidak 
diharuskan datang ke kantor karena belum adanya kantor fisik yang dimiliki hingga saat ini. Freelancer berasal dari abad pertengahan yakni prajurit bayaran (a free lance). Seiring berjalannya waktu, istilah freelancer semakin memiliki arti dan makna tersendiri didunia bisnis yakni seorang pekerja lepas [2].

Salah satu manfaat dari bekerja secara freelance adalah pekerjaan dapat dikerjakan kapan saja dan dimana saja. Dengan begini, para mahasiswa dapat bekerja dan memiliki penghasilan sendiri. Freelance juga memberikan kesempatan kepada para pekerjanya yang memiliki masalah seperti jarak antar rumah dan kantor yang cukup jauh. Namun, terdapat beberapa masalah yang sering timbul seperti lalainya freelancer dalam mengerjakan tugas dan seringnya freelancer $a d a$ yang hilang tanpa kabar setelah bekerja selama satu bulan.

Demi membawakan berita terbaru, Playcubic turut hadir dalam acara-acara besar untuk melakukan kegiatan liputan launching sebuah produk seputar gaming dan produk teknologi lainnya seperti ASUS, HP, Lenovo, Playstation, MSI dan perangkat teknologi lainnya. Dari hasil liputan tersebut, Playcubic diberikan kesempatan untuk melakukan tinjauan produk dan dipinjami produk yang baru diluncurkan tersebut. Hasil wawancara dengan narasumber Bapak Romi Sugara selaku Manajer dari Playcubic bahwa, penerapan dan pemanfaatan teknologi informasi pada Playcubic belum dimanfaatkan secara maksimal. Sehingga masih terdapat beberapa kelemahan didalam sistem manajerial saat ini.

Dari hasil wawancara dengan narasumber terkait perihal Playcubic, peneliti menemukan beberapa kelemahan dan kekurangan dalam kegiatan pengelolaan freelancer yang dapat dijelaskan sebagai berikut: Proses pembagian tugas masih menggunakan media Whatsapp dan sangat rentan akan kesalahan yang sering dilakukan oleh manusia (human error) seperti, kesalahan dalam memberikan info kepada orang yang berbeda dan kurang adanya manajemen untuk menyimpan data yang dapat menyebabkan redudansi data; Proses penggajian masih dilakukan via Whatsapp dan sangat sulit untuk memberikan informasi lengkap mengenai jumlah saldo yang dihasilkan oleh masing-masing penulis; Sistem inventori barang yang masih manual yakni semua barang yang dipinjamkan masih ditulis didalam kertas sehingga dapat beresiko kehilangan data; dan Manajer, Keuangan dan Admin yang bekerja secara terpisah harus saling mengirim data setiap waktu agar dapat mendapatkan data terbaru karena data yang dipegang oleh masing-masing pihak berbeda topik dan keterbaruan datanya. Tak jarang terdapat data yang masih ditulis kedalam kertas dan harus dikirim dalam bentuk foto.

Dengan adanya resiko-resiko tersebut, peneliti ingin membantu Playcubic dengan cara membangun sebuah sistem informasi berbasis web pada Playcubic agar dapat menangani masalah-masalah yang terjadi pada Playcubic.

Berdasarkan uraian yang telah dideskripsikan di latar belakang, maka terdapat rumusan masalah yang terbagi menjadi beberapa poin penting yakni, Bagaimana merancang dan membangun sistem yang dapat membantu sistem pengelolaan freelancer dalam mengolah data freelancer, inventori, pembagian judul artikel, liputan dan penggajian bagi freelancer Playcubic?

Untuk membatasi masalah yang telah diidentifikasi dalam penelitian ini, maka terdapat beberapa batasan yang terbagi sebagai berikut: Pembuatan Sistem Informasi berbasis web ini hanya dapat diakses oleh anggota karyawan terkait perusahaan Playcubic; Sistem Informasi berbasis web ini dapat membantu manajer dalam mengolah data freelancer, inventori, pembagian judul artikel, liputan dan penggajian bagi freelancer Playcubic; Sistem informasi berbasis web ini menggunakan bahasa pemrograman PHP dengan basis data MySQL; dan Sistem Informasi ini hanya dapat digunakan pada bagian internal Playcubic.

Tujuan yang ingin dicapai dalam penelitian ini adalah membangun sebuah sistem berbasis komputer pada perusahaan media massa Playcubic untuk melakukan pengelolaan dalam mengolah data freelancer, inventori, pembagian topik artikel, liputan dan penggajian. Data-data ini juga dapat terhubung dan terintegrasi satu sama lain agar dapat memudahkan admin dalam melakukan pendataan serta melakukan kegiatan manajerial dengan lancar.

\section{METODOLOGI PENELITIAN}

\section{A. Penelitian Terdahulu}

Sebelumnya banyak dilakukan penelitian terdahulu mengenai Sistem Informasi Manajemen Sumber Daya Manusia yang erat kaitannya dengan Sistem Informasi Pengelolaan Freelancer oleh Diah Puspitasari. Penelitian pertama memiliki judul Rancang Bangun Sistem Informasi Koperasi Simpan Pinjam Karyawan Berbasis Web dengan menggunakan Bahasa pemrograman PHP dan pemodelan sisten UML. Penelitian ini dibuat untuk membangun sistem koperasi simpan pinjam karyawab berbasis web [3]. 
Penelitian kedua dilakukan oleh Yesri Elva yang berjudul Perancangan sistem Informasi Kepegawaian Berbasis WEB Pada Badan Kepegawaian Daerah (BKD) dengan menggunakan bahasa scripting PHP dan Database MySQL. Dalam penelitian ini mengkaji tentang bagaimana merancang sistem informasi manajemen yang dapat memudahkan dalam mengintegrasikan data dan menjadi media penyampaian kepada pengguna. Sistem yang dirancang berbasis website ini menggunakan bahasa pemrograman PHP dengan basis data MySQL dan dibangun berdasarkan teknik UML. Penelitian ini juga dibuat untuk mengatasi masalah dalam penyebaran informasi pada BKD [4].

\section{B. Instrumen Penelitian}

Instrumen penelitian merupakan alat bantu yang dapat digunakan dalam suatu penelitian. Adapun instrumen penelitian yang digunakan oleh peneliti selama proses pengambilan/pengumpulan data-data penelitian yakni:

Hasil Wawancara, Wawancara langsung diadakan dan ditangani oleh narasumber Bapak Romi Sugara selaku manajer dari Playcubic. Peneliti menggunakan alat bantu seperti smartphone untuk merekam suara dan media kertas untuk mencatat jawaban dari narasumber. Melalui hasil wawancara, peneliti dapat mengumpulkan berbagai informasi seperti undangan dan informasi lain mengenai rumusan masalah dan kebutuhan sistem untuk merancang sistem yang baru.

Hasil Observasi Langsung, Observasi dilakukan di kantor Playcubic meliputi pengamatan dan pengumpulan data terhadap proses bisnis dan cara kerja sistem lama pada Playcubic yang berlokasi di Jln. Bambu Kuning No. 10 RT. 02 RW. 01 Kelurahan Jati Padang Kecamatan Pasar Minggu. Peneliti menggunakan media kertas sebagai alat bantu pencatatan.

\section{Kerangka Berpikir Penelitian}

Penulis menggunakan kerangka berpikir sebagai alat untuk menggambarkan alur dari proses penelitian dalam pembuatan sistem. Sistem merupakan kumpulan orang yang bekerja sama dengan ketentuanketentuan aturan dengan tujuan untuk melaksanakan fungsi dengan cara membentuk satu-kesatuan. Sistem memiliki karakteristik yang terdiri dari komponen sistem, batasan sistem, lingkungan luar sistem, penghubung sistem dan sasaran sistem [5].

Didalam kerangka berpikir terdapat tahaptahap yang akan dilakukan oleh penulis diantaranya:
Peneliti melakukan analisis kebutuhan sistem dari permasalahan yang ditemui berdasarkan hasil wawancara dan observasi yang terjadi pada Playcubic. Peneliti lalu melakukan pembelajaran melalui literatur, jurnal, buku dan penelitian terdahulu yang terkait dengan sistem informasi pengelolaan sumber daya manusia. Dari hasil pengamatan dan penarikan akar permasalahan, peneliti lalu mengumpulkan hasil analisa yang akan dibangun berdasarkan kebutuhan fungsional dan non fungsional yang ada. Peneliti menggunakan alat bantu seperti flowchart untuk dapat menjelaskan lebih rinci mengenai proses bisnis pada sistem tersebut; Tahap selanjutnya peneliti akan membuat prototype sistem yang sesuai dengan kebutuhan sistem menggunakan UML yang terdiri dari use case diagram, activity diagram, class diagram dan sequence diagram; Peneliti akan melakukan penyesuaian mengenai prototype kepada pengguna untuk memastikan bahwa prototype telah sesuai dengan kebutuhan system; Jika prototype sudah sesuai dengan kebutuhan sistem, peneliti selanjutnya akan melakukan pembangunan sistem berdasarkan kebutuhan sistem pada prototype; Sistem akan dilakukan uji coba oleh peneliti dan juga oleh pengguna. Jika sistem yang dibangun masih belum sesuai dengan kebutuhan sistem, maka peneliti akan melakukan penyesuaian kembali hingga sistem telah sempurna; dan Sistem yang sudah sempurna akan dibangun secara detail dan mampu digunakan oleh

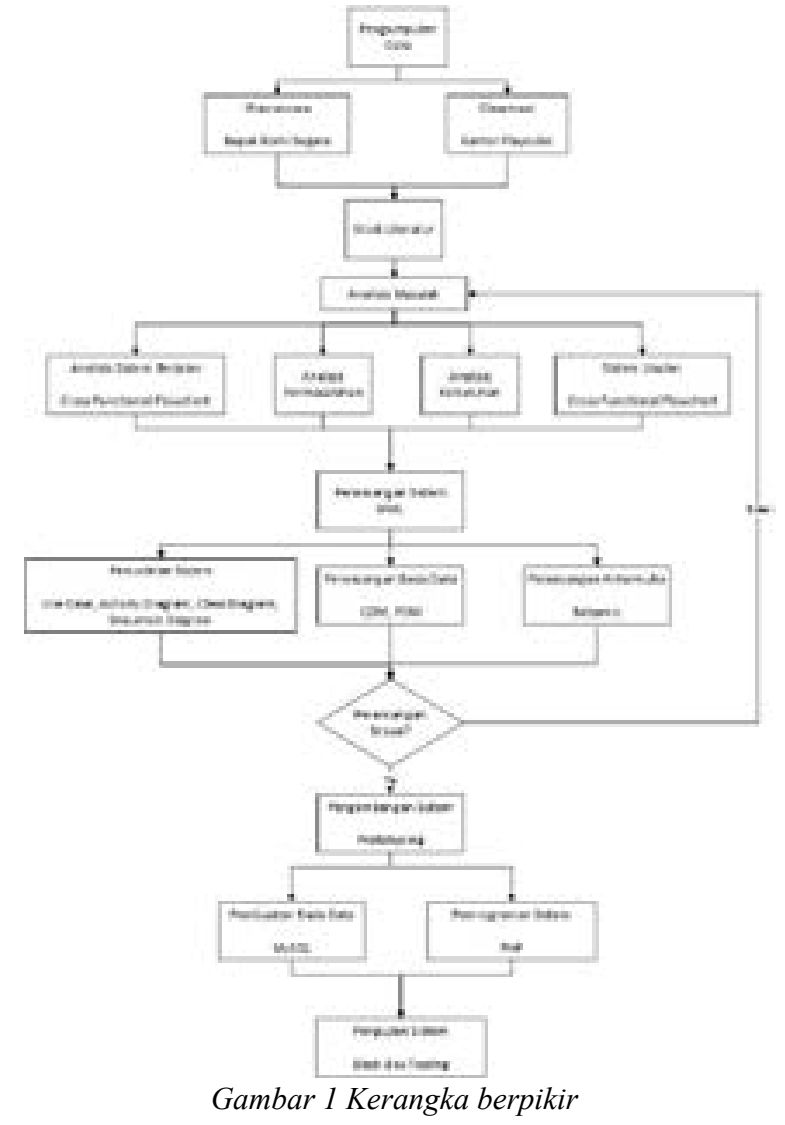


pengguna. Selama melakukan penelitian, penulis menggunakan kerangka berpikir seperti ditunjukkan pada Gambar 1.

\section{HASIL DAN PEMBAHASAN}

\section{A. Profil Perusahaan}

Playcubic merupakan perusahaan startup yang bergerak di bidang media massa khususnya membahas seputar teknologi dan video games. Playcubic selalu memberikan berita menarik secara berkala mengenai perkembangan teknologi di industri media dan digital kreatif. Playcubic didirikan pada tahun 2012 oleh ketiga founder masing-masing adalah Bapak Romy Sugara, Bimo Aryoaji, Sultrio Mandruppai.

\section{B. Analisis Sistem Berjalan}

Berdasarkan data yang telah peneliti kumpulkan sebelumnya, peneliti akan menggunakan cross functional flowchart sebagai alat untuk menggambarkan proses sistem informasi yang sedang berjalan pada Playcubic saat ini. Sistem informasi merupakan kumpulan elemen yang membentuk suatu kesatuan dalam mengintegrasikan, memproses dan mendistribusikan informasi. Sistem informasi terdiri dari banyak komponen seperti komponen blok model, blok masukan, blok keluaran, blok kendali dan blok teknologi. Sehingga sistem informasi merupakan sistem yang mampu menyediakan informasi yang bermanfaat kepada penggunanya [6].

Terdapat beberapa proses yang terjadi dalam sistem informasi pengelolaan freelancer pada Playcubic, diantaranya adalah: Proses Pembagian Judul Artikel meliputi: Manajer membagikan judul

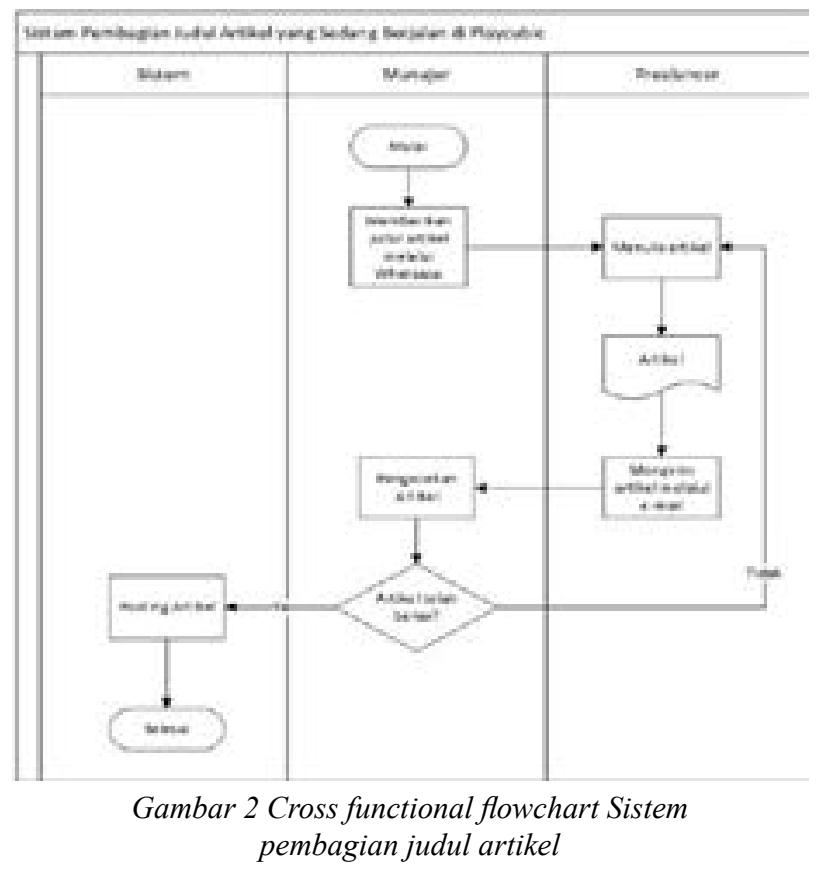

artikel melalui aplikasi Whatsapp; Freelancer menerima judul artikel; Freelancer akan mengerjakan artikel dengan jangka waktu tertentu dan akan mengirim artikel yang telah selesai ditulis melalui e-mail; Manajer akan menerima e-mail dan melakukan pengecekan kembali. Apabila terdapat hal yang dikoreksi, Manajer akan menghubungi freelancer melalui Whatsapp; Freelancer akan kembali mengirim artikel yang telah diperbaiki melalui email; dan Artikel yang telah diperbaiki akan diposting oleh Manajer. Proses analisis pada proses pembagian artikel akan digambarkan kedalam Cross Fuctional Diagram pada gambar 2

Proses Pembagian Liputan meliputi: Manajer mengirim undangan kepada freelancer melalui Whatsapp; Apabila freelancer bersedia datang ke acara tersebut, maka manajer akan mengirim undangan. Namun jika freelancer tidak dapat menghadiri acara liputan, maka manajer tidak akan mengirim undangan; Freelancer yang telah menghadiri acara liputan akan menulis artikel liputan; Freelancer mengirim artikel mengenai acara tersebut kepada manajer melalui e-mail; Manajer akan menerima artikel dan melakukan pengecekan artikel; Apabila terdapat hal yang dikoreksi, manajer akan menghubungi freelancer melalui Whatsapp; Freelancer akan kembali mengirim artikel yang telah diperbaiki melalui email; dan Artikel yang telah diperbaiki akan diposting oleh Manajer. Proses analisis pada proses pembagian liputan akan digambarkan kedalam Cross Fuctional Diagram pada Gambar 3

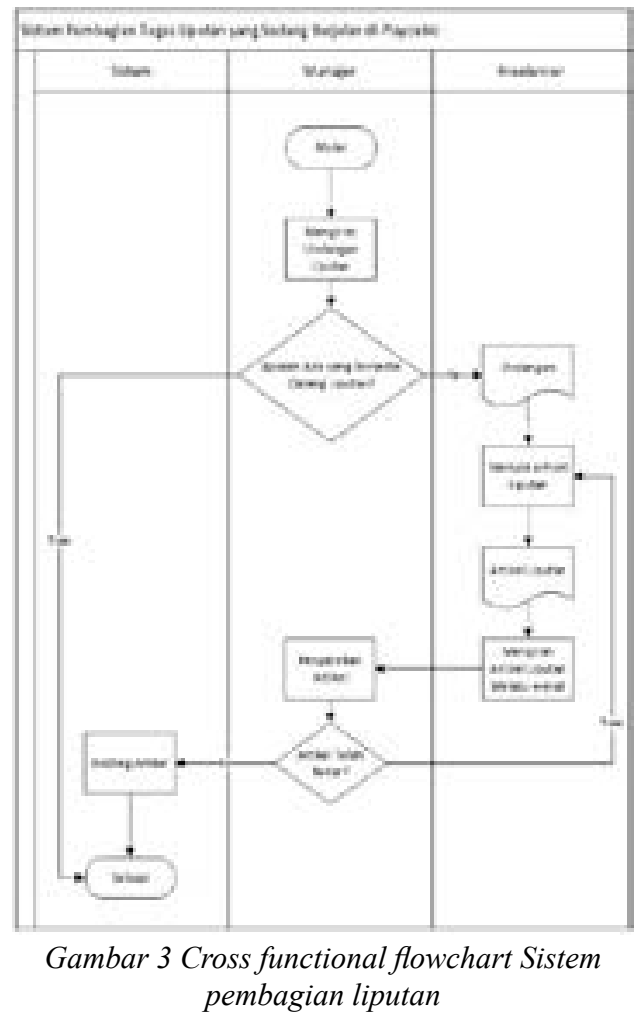


Proses Ulasan Produk meliputi: Manajer akan menghubungi vendor untuk minta kerja sama; Vendor memberikan barang kepada freelancer untuk dilakukan ulasan mengenai produk; Freelancer menulis artikel hasil ulasan produk; Freelancer yang sudah melakukan ulasan produk akan mengirimkan artikel melalui e-mail ke manajer dan mengirimkan produk ke manajer melalui Go-Send; Manajer akan menerima artikel dan melakukan pengecekan artikel; Apabila terdapat hal yang dikoreksi, manajer akan menghubungi freelancer melalui Whatsapp; Freelancer akan kembali mengirim artikel yang telah diperbaiki melalui email; dan Artikel yang telah diperbaiki akan diposting oleh Manajer. Proses analisis pada proses ulasan produk akan digambarkan kedalam Cross Fuctional Diagram pada Gambar 4

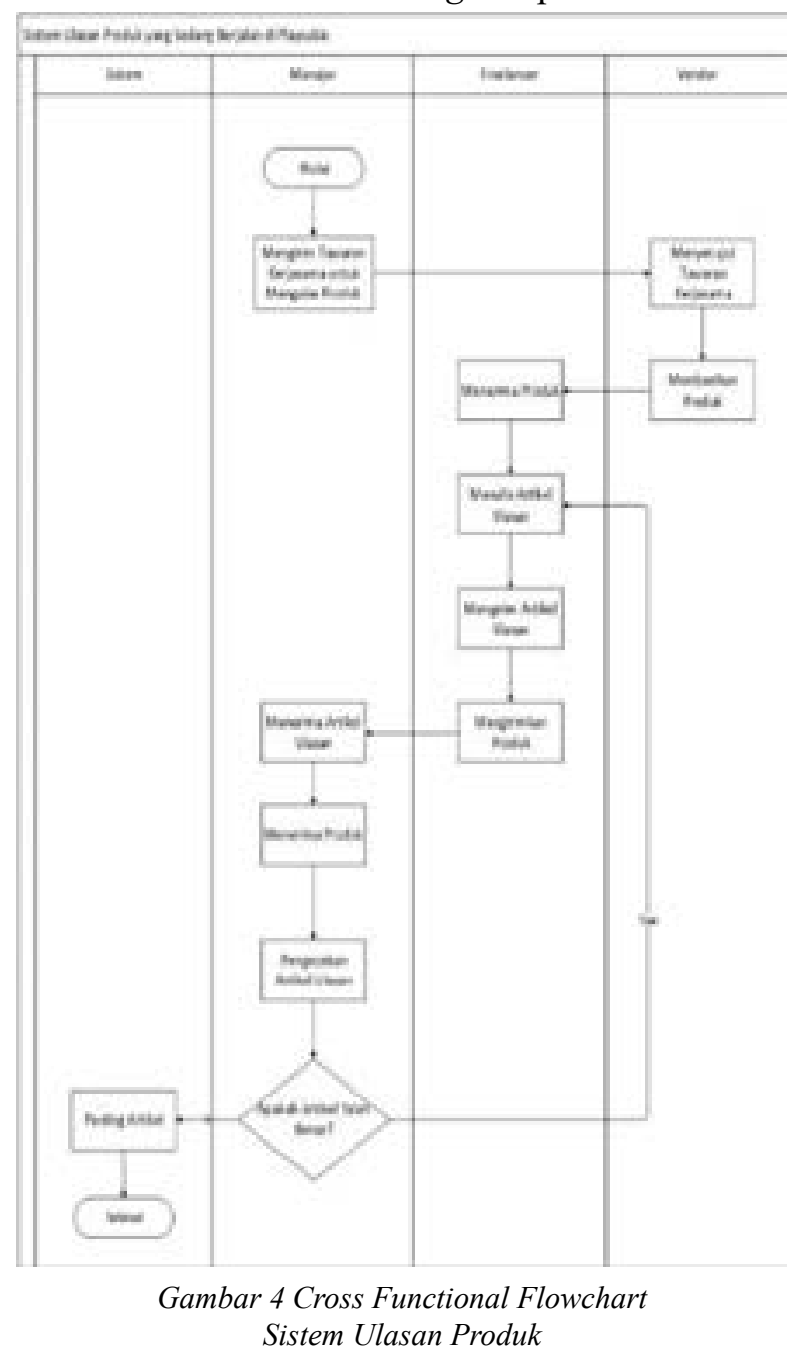

Proses Penggajian Freelancer meliputi: Manajer menghubungi keuangan untuk mengirimkan laporan bahwafreelancer telah mengerjakan artikel; Keuangan melakukan transfer gaji kepada freelancer; Keuangan akan mengirimkan bukti transfer kepada freelancer; dan Freelancer menerima gaji, hal tersebut dapat dilihat pada Gambar 5. Cross Functional Flowchart Sistem Penggajian Freelancer.

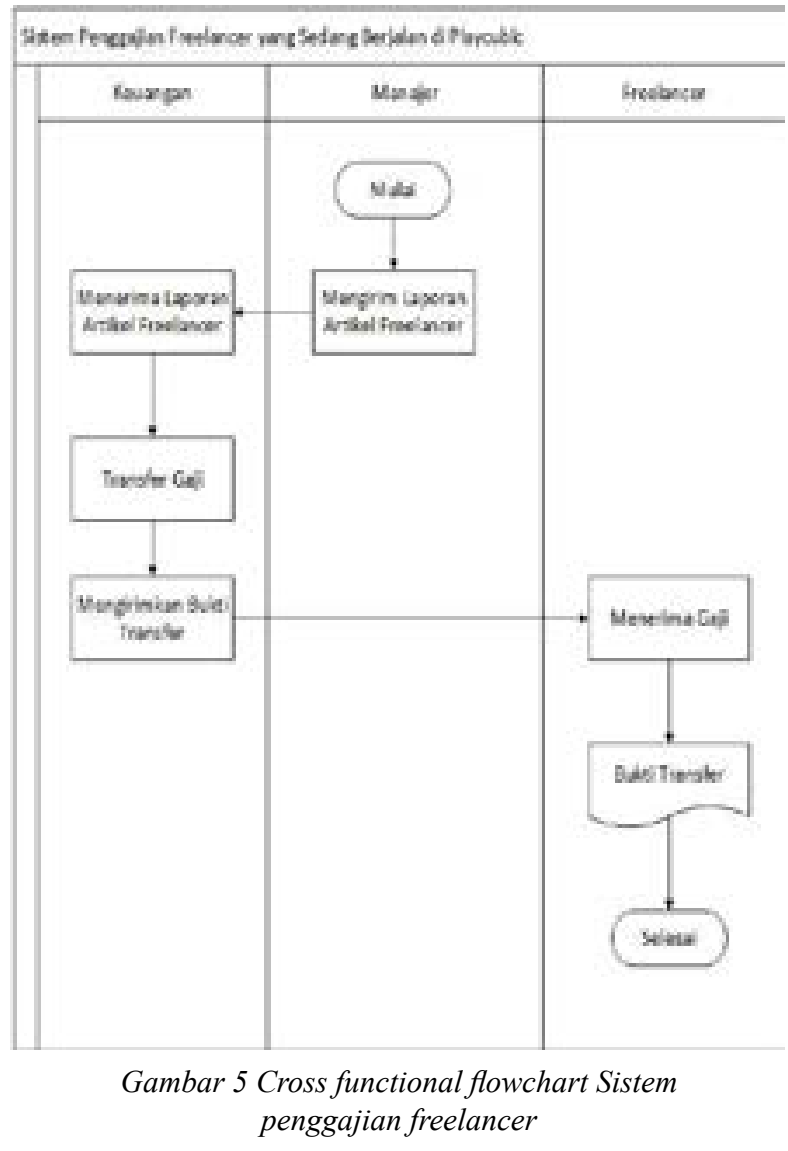

\section{C.Analisis Permasalahan Sistem}

Sebagai alat untuk mengidentifikasi masalah yang ada, peneliti menggunakan fishbone diagram sebagai alat untuk menganlisa karena fishbone diagram mampu dengan baik menggambarkan permasalahan yang tengah dihadapi pada sistem pengelolaan freelancer Playcubic. Peneliti melakukan analisa sistem yang sedang berjalan dengan menggunakan fishbone diagram dengan penjelasannya sebagai berikut: Terdapat beberapa faktor yang menjadi penyebab masalah pada sistem yang sedang berjalan di Playcubic yang terdiri dari faktor utama dan faktor pendukung; Manusia: Manajer harus menghubungi freelancer secara satu per satu dalam pembagian tugas. Tak jarang terjadi kesalahan seperti manajer menghubungi freelancer yang tidak sedang bertugas; Mesin: pembagian tugas masih menggunakan aplikasi Whatsapp serta menggunakan media e-mail secara bersamaan yang dapat mengakibatkan redudansi data; dan Metode: Manajer tidak dapat memantau pekerjaan freelancer. Maka dari itu, manajer menggunakan media Whatsapp untuk membagikan tugas menulis artikel satu-persatu termasuk kedalam konfirmasi pesan dan pembagian gaji.

\section{Analisis Kebutuhan}

Setelah melakukan analisis sistem yang sedang berjalan pada Playcubic, peneliti menjelaskan bahwa 
terdapat dua kebutuhan sistem yakni kebutuhan fungsional dan kebutuhan non fungsional.

\section{Kebutuhan Fungsional}

Dalam melakukan analisis kebutuhan, peneliti menentukan kebutuhan fungsional untuk mengetahui fungsi-fungsi yang terdapat pada sistem. Adapun kebutuhan fungsional terdapat pada Tabel 1

Tabel 1 Kebutuhan fungsional

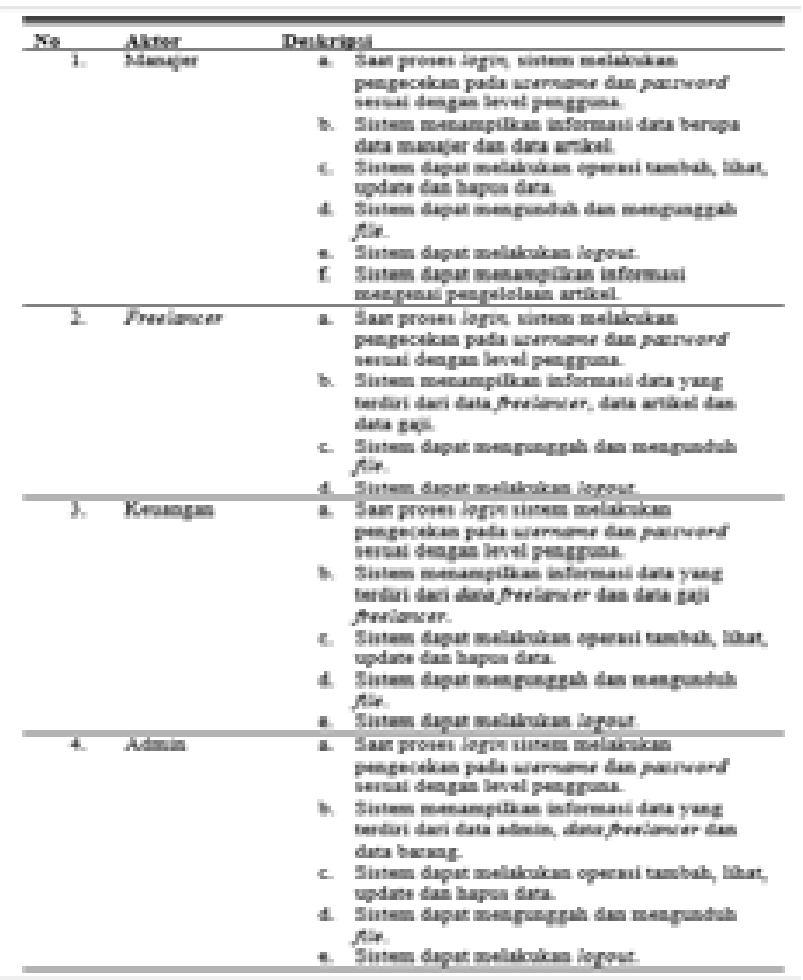

\section{Kebutuhan Non Fungsional}

Kebutuhan non fungsional merupakan kebutuhan yang digunakan untuk mendukung sistem agar dapat berjalan. Adapun kebutuhan non fungsional yang diperlukan dalam membangun sistem ini terdapat pada Tabel 2

Tabel 2 Kebutuhan non fungsional

\begin{tabular}{|c|c|c|}
\hline $\mathrm{Na}$ & Kenepara & Deakripti \\
\hline I. & Perantatat Kerai & 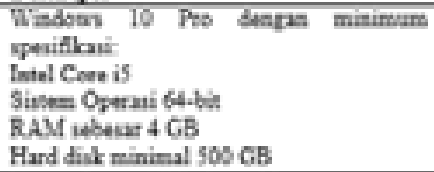 \\
\hline 2. & Perasta: Lunak & 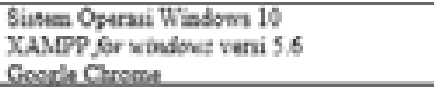 \\
\hline
\end{tabular}

\section{E. Pemodelan Sistem}

UML (Unified Modeling Language) merupakan pemodelan sistem yang terdiri dari klasifikasi struktural, perilaku dinamis dan model manajemen atau yang sering muncul sebagai diagram-diagram seperti use case diagram, class diagram, statechart diagram, activity diagram dan sequence diagram [7].
Untuk melakukan pemodelan sistem, penulis menggunakan alat bantu dengan metode UML meliputi use case diagram, activity diagram, class diagram dan sequence diagram. Pada tahap selanjutnya penulis akan melakukan perancangan pada basis data dan antarmuka pada sistem.

\section{Use Case Diagram}

Use case diagram merupakan bentuk penggambaran dari external view dari sistem yang akan dibuat. Use case memiliki komponen seperti aktor, aktivitas dan hubungan[8].

Dalam merancang sistem yang akan dibuat, penulis menggunakan use case diagram sebagai alat untuk memperlihatkan hubungan antara aktor dengan sistem. Pada Gambar 6 terdapat empat aktor yang masing-masing memiliki interaksi pada sistem yang terdiri dari aktor manajer yang dapat mengelola artikel dan mengelola undangan, freelancer yang dapat melihat, mengunggah dan mengunduh artikel serta undangan. Terdapat aktor lain seperti admin yang dapat mengelola data freelancer dan mengelola data barang serta bagian keuangan yang dapat mengelola data gaji freelancer.

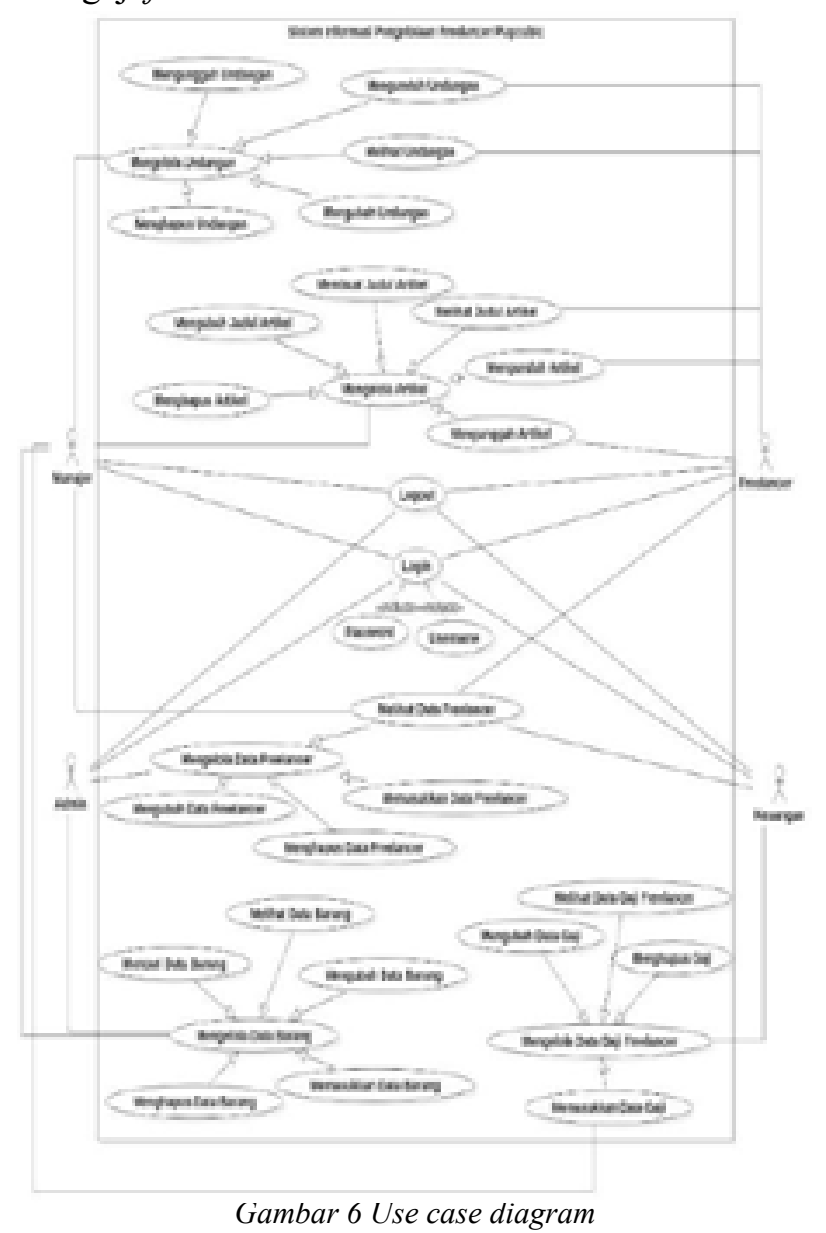

\section{Activity Diagram}

Activity diagram merupakan alat yang digunakan oleh penulis untuk menggambarkan 
alur kerja pada sistem usulan berdasarkan use case diagram yang telah dirancang sebelumnya[9]. Pada activity diagram, penulis membagi diagram-diagram tersebut sesuai dengan masing-masing pengguna.

\section{a. Pengguna}

Pengguna merupakan pelaku yang terlibat pada sistem dan memiliki hak akses sesuai dengan role masing-masing. Pengguna terdiri dari manajer, administrator, freelancer dan keuangan.

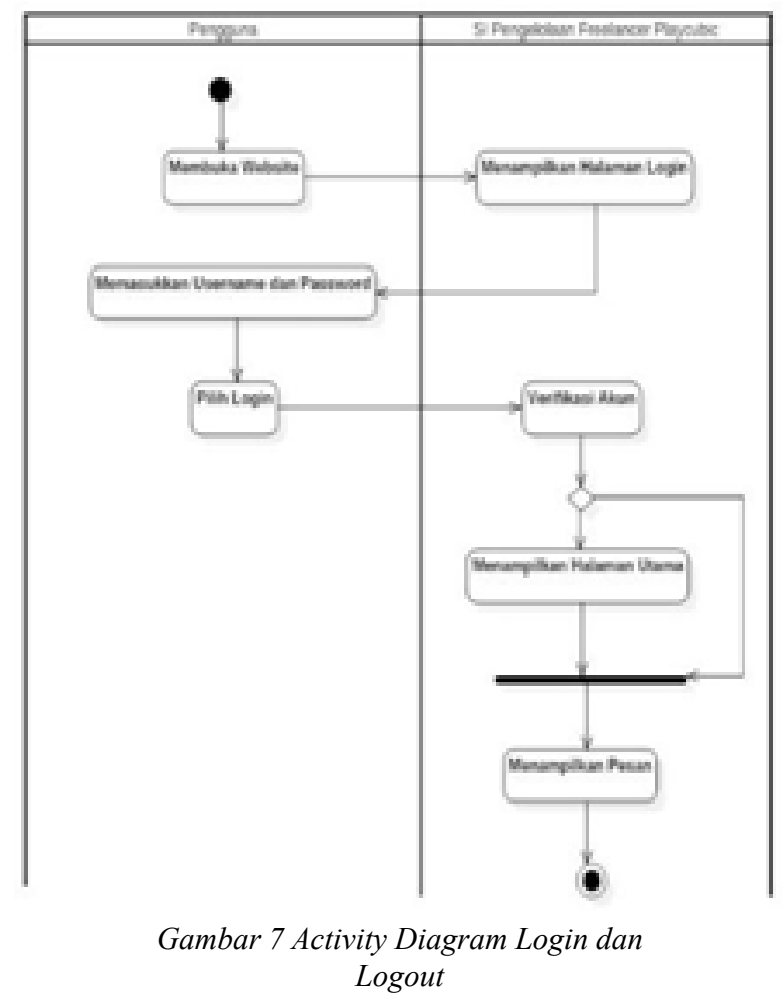

Gambar 7 menunjukkan aktivitas yang dilakukan oleh pengguna dalam melakukan kegiatan login dan logout. Pengguna dapat masuk kedalam sistem dengan melakukan proses login terlebih dahulu. Setelah selesai melakukan kegiatan pada sistem, pengguna dapat keluar dari sistem dengan melakukan logout.

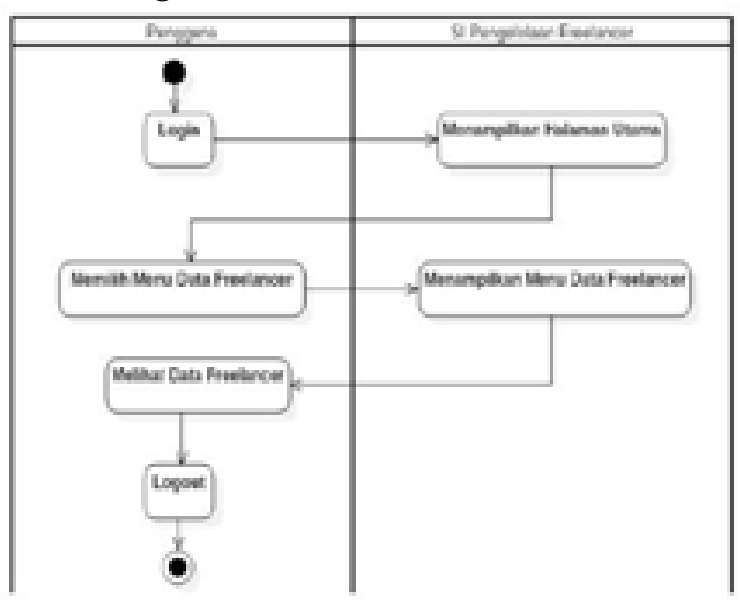

Gambar 8 Activity Diagram Melihat Data Freelancer
Gambar 8 menunjukkan aktvitas yang dilakukan oleh para pengguna dalam melihat data freelancer. Pengguna dapat melihat informasi mengenai freelancer yang terdiri dari nama, alamat, jumlah artikel yang telah ditulis dan nomor telepon.

\section{b. Manajer}

Manajer dapat melakukan aktivitas pada sistem mencakup pengelolaan artikel dan pengelolaan terhadap undangan liputan.

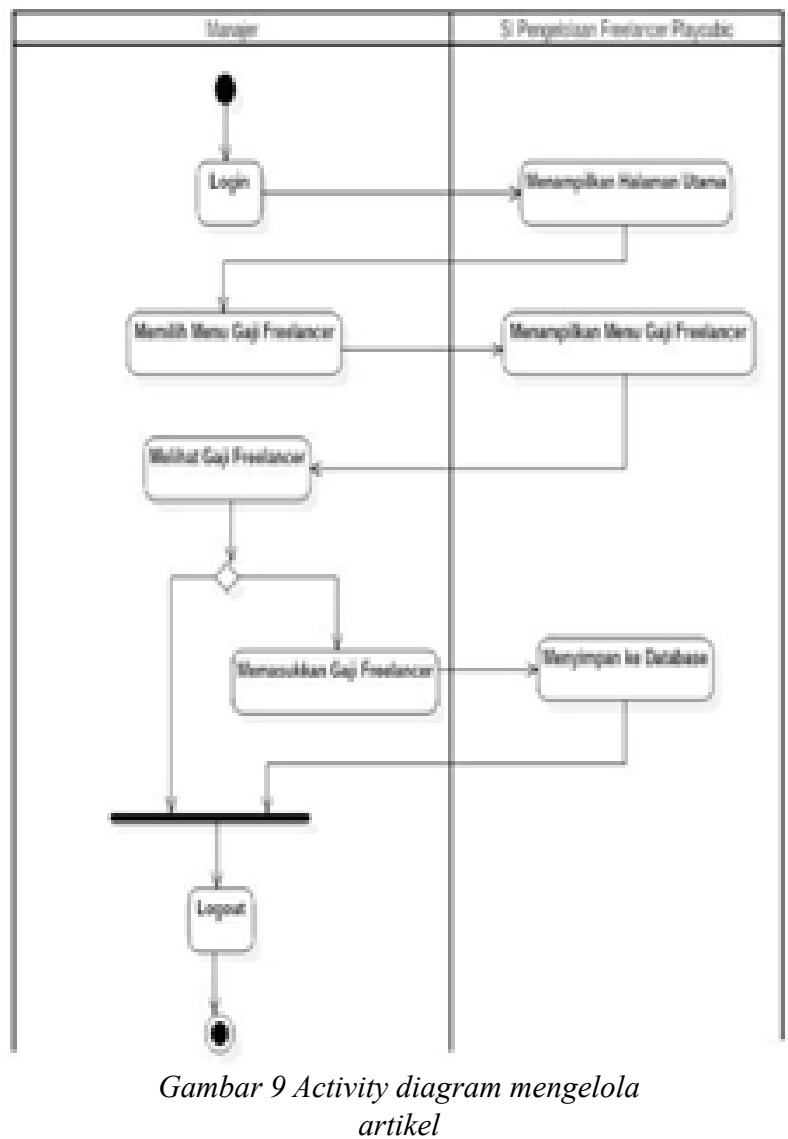

Gambar 9 menunjukkan aktivitas yang dilakukan oleh manajer dalam mengelola data artikel meliputi melihat, memasukkan, mengubah, mengunduh dan mengunggah artikel. Setiap aktivitas yang dilakukan oleh manajer akan diproses oleh sistem.

Gambar 10 menunjukkan aktivitas yang dilakukan oleh manajer untuk melihat data barang. Manajer memiliki hak akses untuk melihat barang pada menu barang. Setelah selesai mengakses menu barang, manajer dapat keluar dari sistem dengan melakukan proses logout.

Gambar 11 menjelaskan tentang activity diagram untuk mengelola undangan liputan oleh manajer. Manajer memiliki hak akses untuk melakukan manipulasi data undangan. Setiap aktivitas yang dilakukan oleh manajer akan direspon oleh sistem dengan menyimpan semua perubahan data dan masukkan data kedalam sistem. 


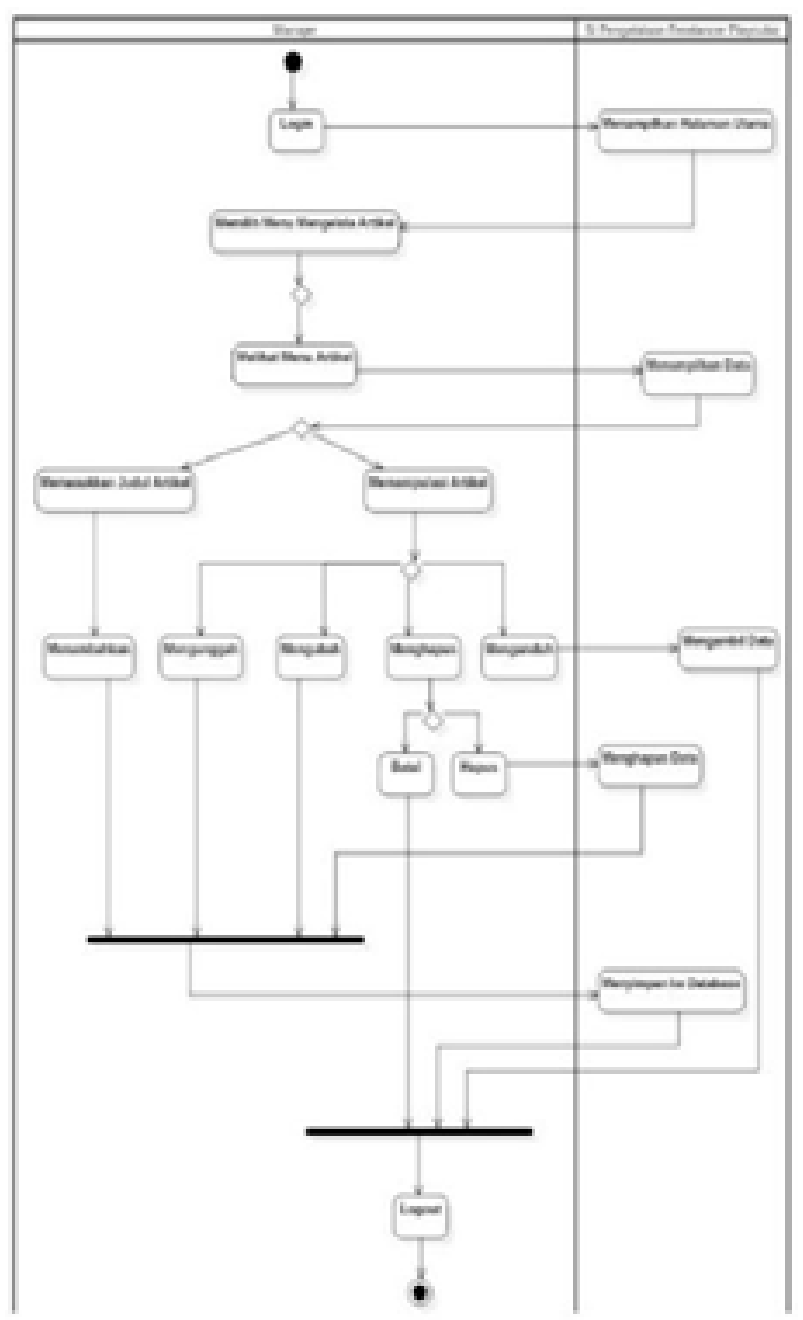

Gambar 10 Activity diagram melihat data barang

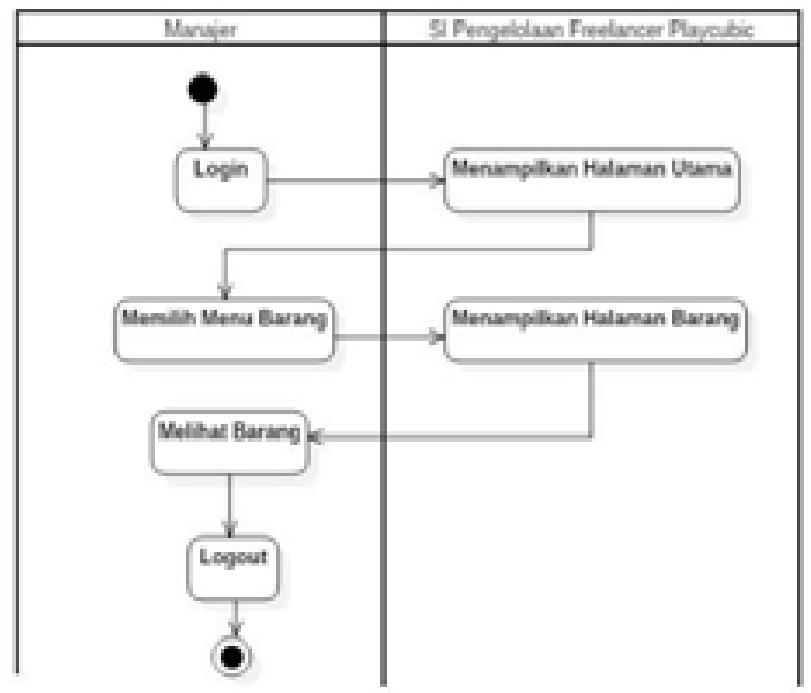

Gambar 11 Activity diagram mengelola undangan liputan

Gambar 12 menunjukkan aktivitas yang dilakukan oleh manajer untuk memasukkan gaji freelancer. Setelah masuk kedalam sistem, manajer dapat mengakses menu gaji freelancer dan memasukkan jumlah gaji freelancer.

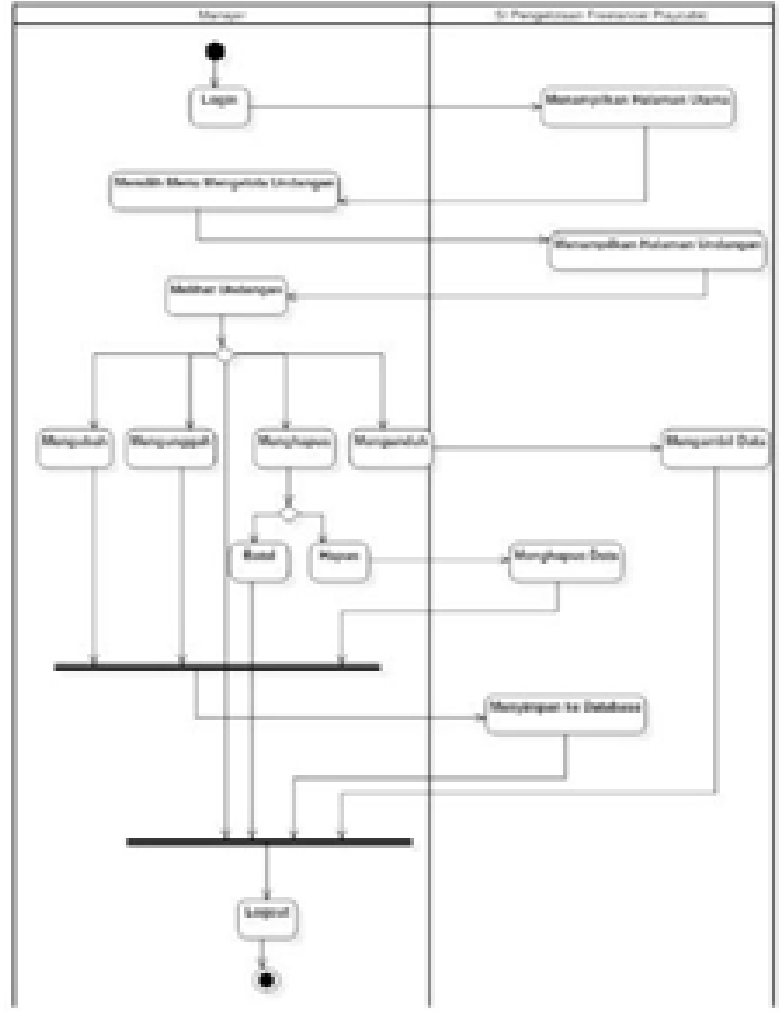

Gambar 12 Activity diagram memasukkan gaji freelancer

\section{c. Freelancer}

Freelancer memiliki hak akses pada sistem yang cukup terbatas meliputi melihat judul artikel, mengunggah artikel, mengunduh artikel dan mengunduh undangan liputan.

Gambar 13 menunjukkan aktivitas yang dilakukan oleh freelancer dalam mengelola artikel.

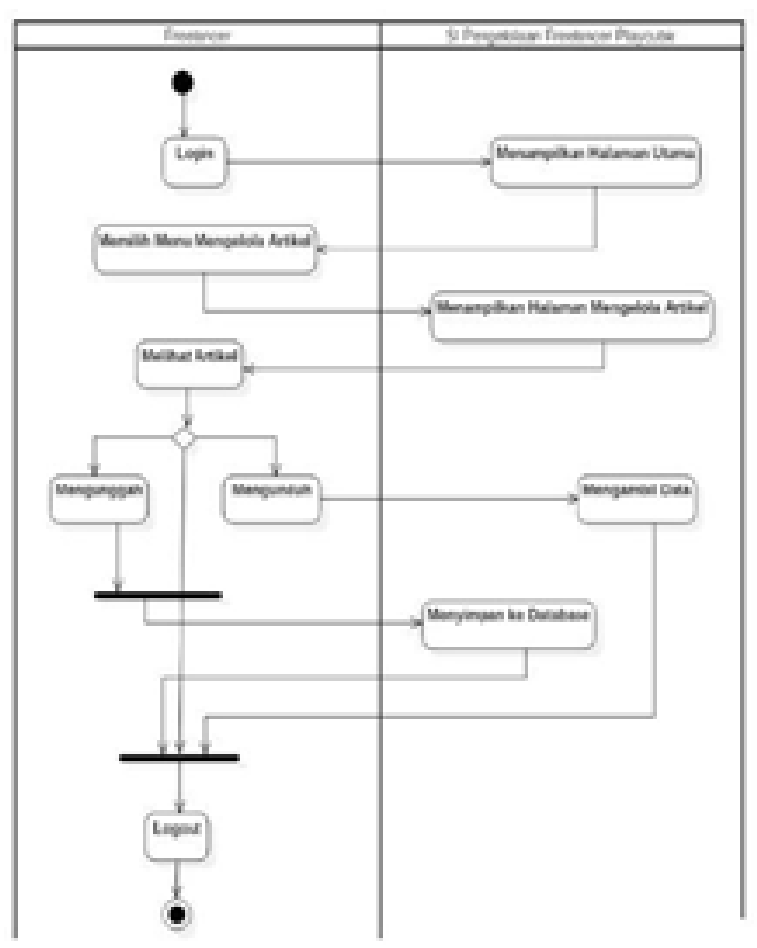

Gambar 13 Activity diagram mengelola artikel 


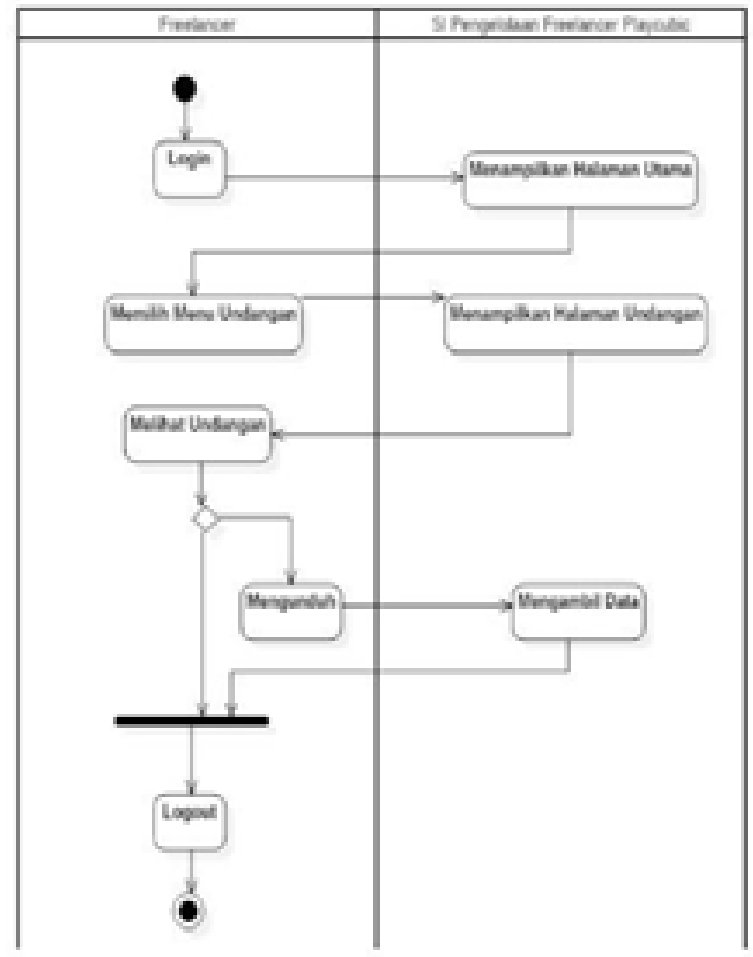

Gambar 14 Activity Diagram Undangan

Freelancer

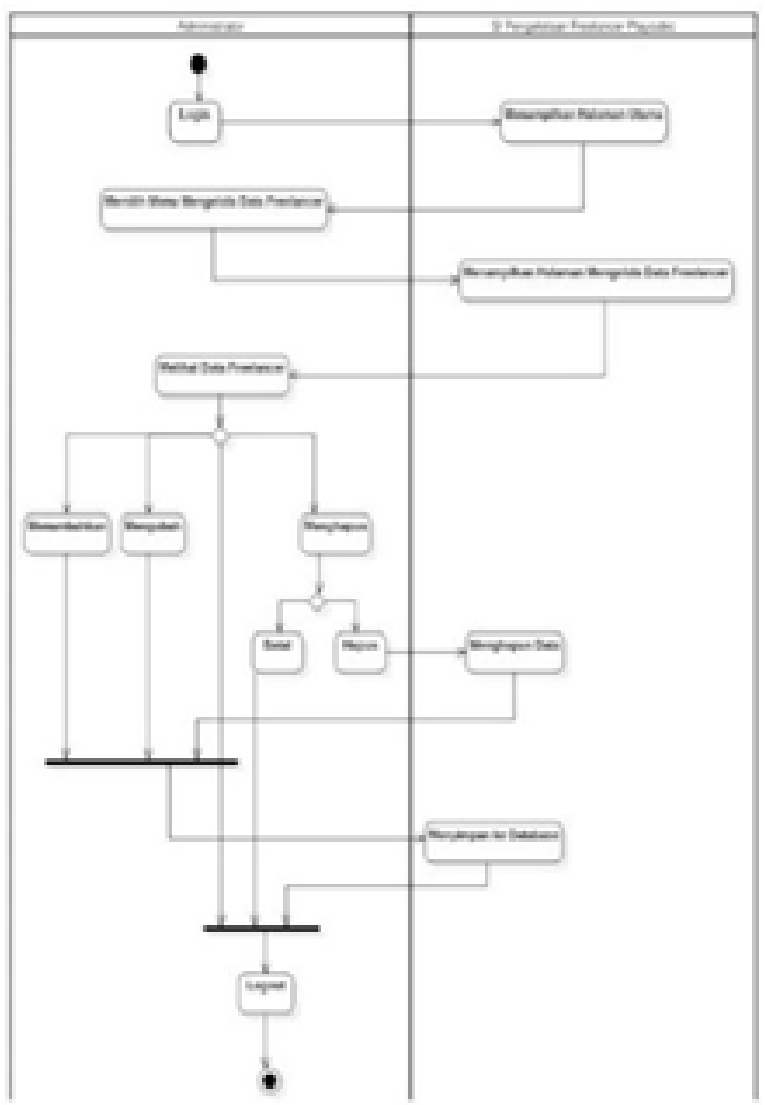

Gambar 15 Activity Mengelola Data Freelancer

Freelancer dapat mengakses menu artikel dan dapat melakukan kegiatan seperti melihat artikel, mengunggah serta mengunduh artikel.

Pada Gambar 14 menjelaskan tentang activity diagram untuk mengunduh data undangan.
Freelancer memiliki hak akses untuk mengunduh undangan liputan melalui sistem. Lalu sistem akan mengambil data undangan dari sistem untuk dapat diunduh oleh freelancer.

\section{d. Administrator}

Administrator dapat melakukan aktivitas meliputi mengelola data freelancer dan mengelola data barang.

Pada Gambar 15 menjelaskan tentang aktivitas mengelola data freelancer yang dilakukan oleh admin pada sistem. Admin dapat melakukan kegiatan seperti melihat, mengubah, menghapus dan menambahkan data freelancer.

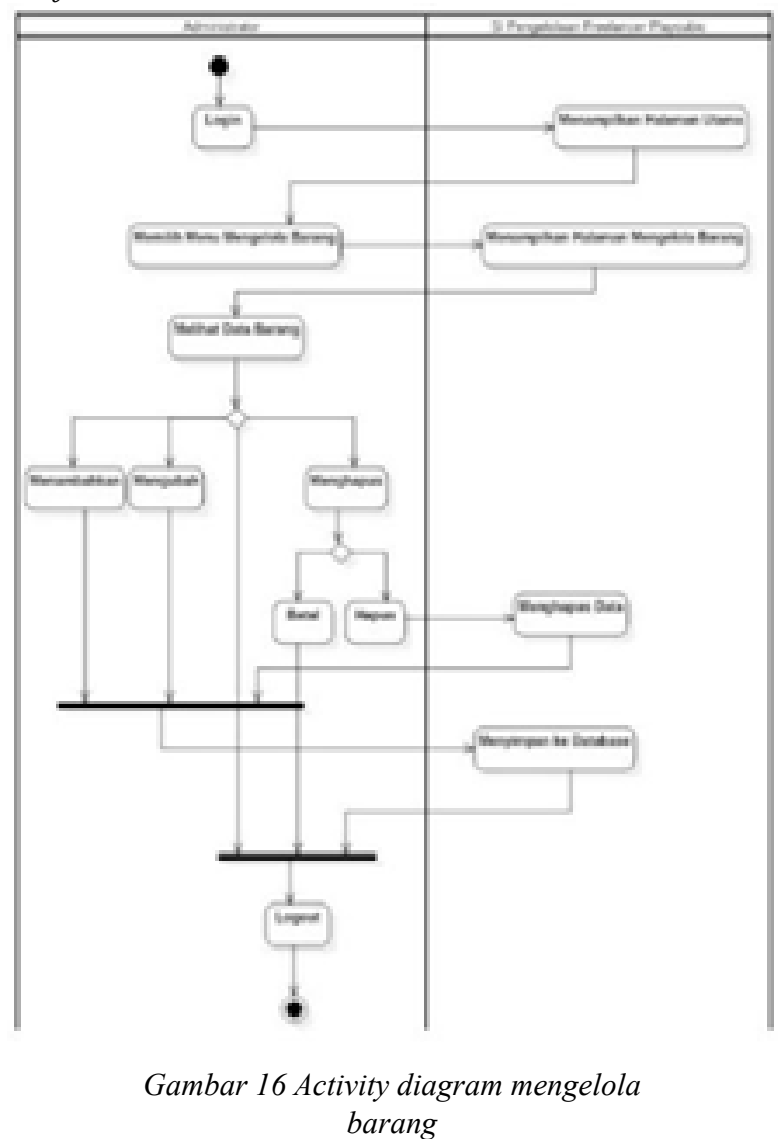

Pada Gambar 16 menjelaskan tentang aktivitas mengelola data barang yang dilakukan oleh admin pada sistem. Admin dapat melakukan kegiatan seperti melihat, mengubah, menghapus dan menambahkan data barang. Data yang sudah dimanipulasi akan diproses pada sistem.

\section{e. Keuangan}

Keuangan dapat melakukan aktivitas yang terdiri dari mengelola data gaji freelancer. Pada Gambar 17 menjelaskan tentang aktivitas untuk keuangan dalam mengelola data gaji freelancer. Keuangan memiliki tugas untuk memasukkan data gaji freelancer. Keuangan juga memiliki hak akses untuk 


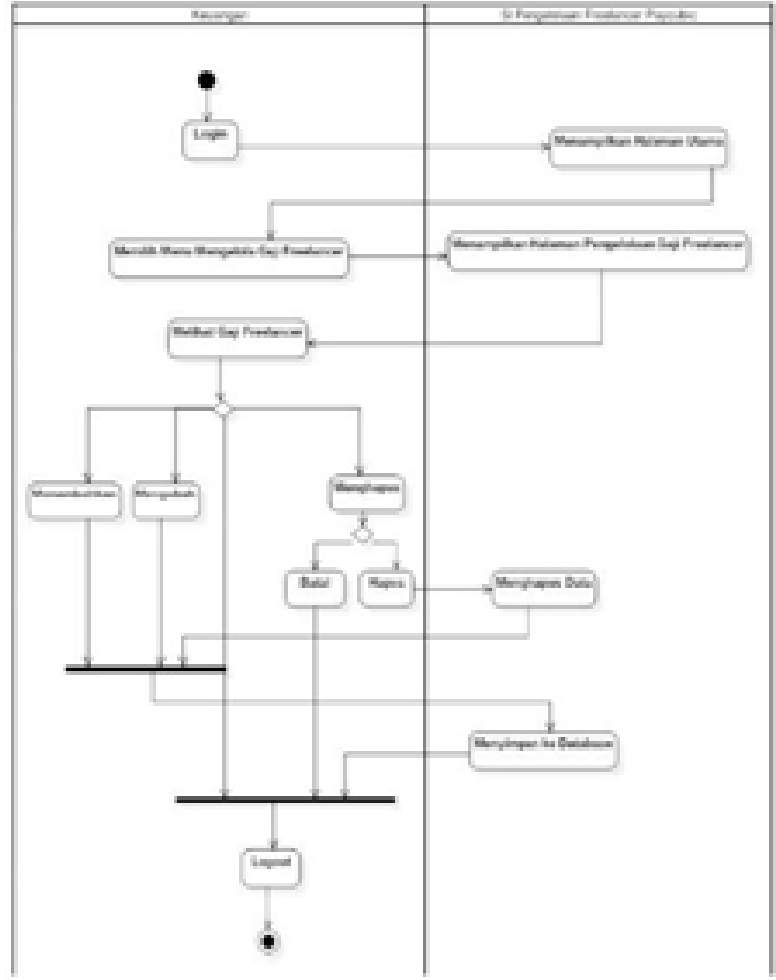

Gambar 17 Activity diagram mengelola Gaji freelancer

memanipulasi data seperti memasukkan melihat, mengubah dan menghapus data gaji freelancer.

\section{Class Diagram}

Class diagram menggambarkan struktur sistem dalam sebuah kelas-kelas yang menjelaskan rancangan dari sistem yang sedang dibangun[10]. Diagram kelas memiliki tujuan sebagai rancangan sehingga dokumentasi perancangan dan perangkat lunak yang dihasilkan saling cocok.

\section{Sequence Diagram}

Sequence diagram menggambarkan secara menyeluruh mengenai interaksi antara user dengan sistem. Sequence diagram berasal dari use case diagram yang sebelumnya telah dibuat dengan menjelaskan antara waktu hidup dan pesan (message) yang diterima antar objek[11]. Seperti Gambar 18.

\section{a. Pengguna}

Pengguna merupakan pelaku yang terlibat pada sistem dan memiliki hak akses sesuai dengan role masing-masing. Pengguna terdiri dari manajer, administrator, freelancer dan keuangan. Pengguna secara umum dapat mengakses sistem seperti yang ditunjukkan pada gambar 19 dan gambar 20.

Gambar 19 menunjukkan kegiatan yang berjalan ketika pengguna ingin masuk kedalam sistem dan
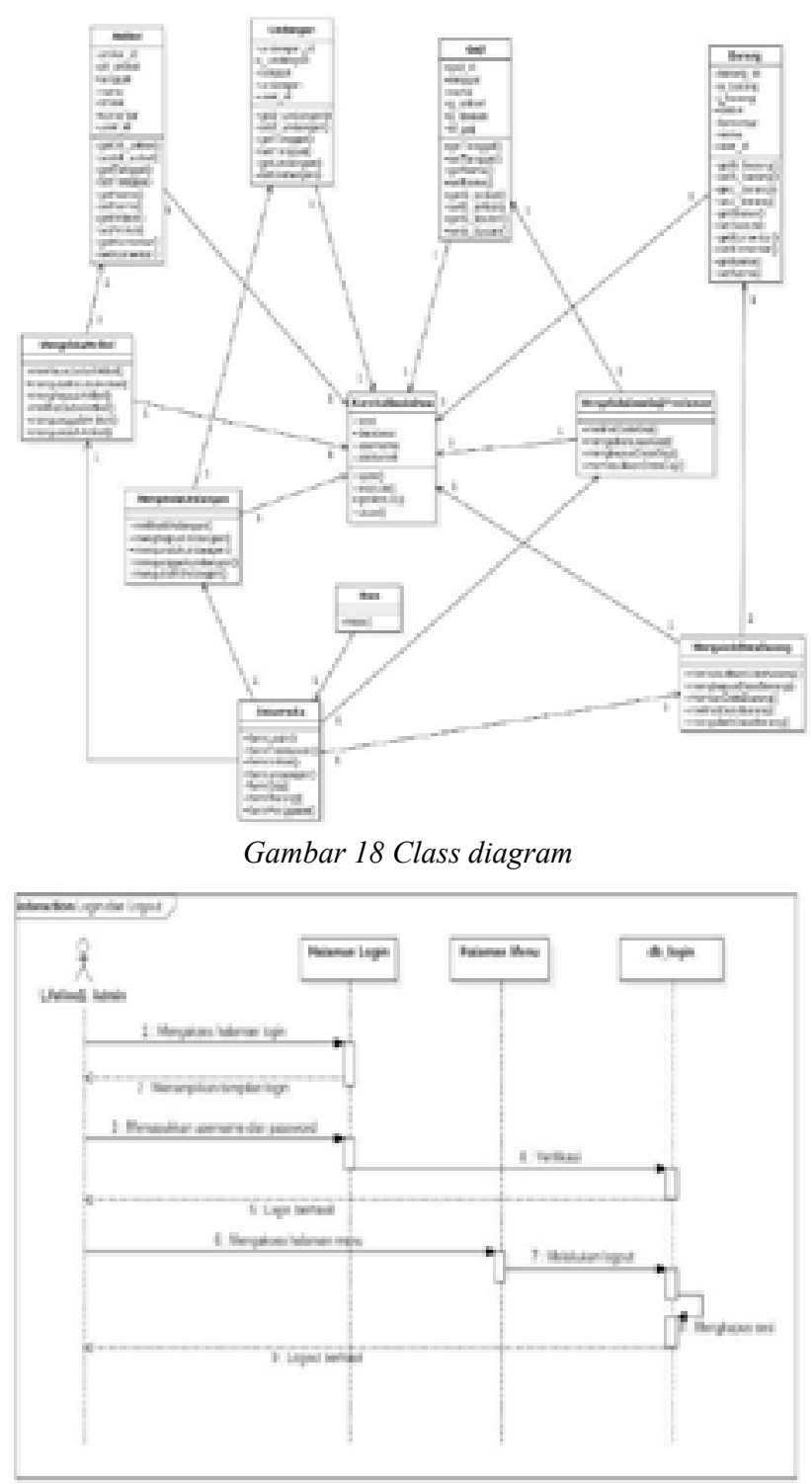

Gambar 19 Sequence diagram login dan logout

keluar dari sistem. Saat melakukan proses login, pengguna diminta untuk memasukkan username dan password terlebih dahulu. Ketika proses login berhasil, maka pengguna dapat mengakses halaman utama. Proses logout akan mengirimkan informasi ke basis data untuk berpindah ke halaman login.

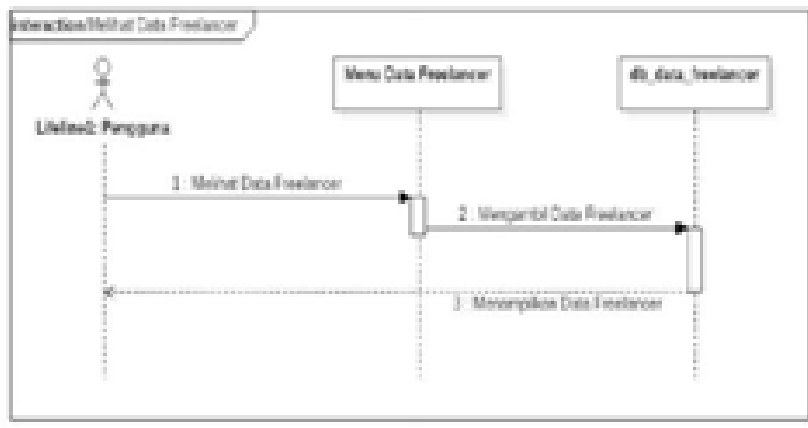

Gambar 20 Sequence diagram melihat data freelancer 
Gambar 20 menunjukkan kegiatan pengguna dalam mengakses menu freelancer. Pengguna dapat melihat data freelancer yang terdiri dari nama, alamat, nomor telepon dan jumlah artikel yang telah dikerjakan.

\section{b. Manajer}

Manajer merupakan aktor yang mendeskripsikan waktu hidup dalam beberapa aktivitas yang dilakukan oleh manajer diantaranya mengelola antarmuka dan database yang saling mengirim dan menerima suatu objek.

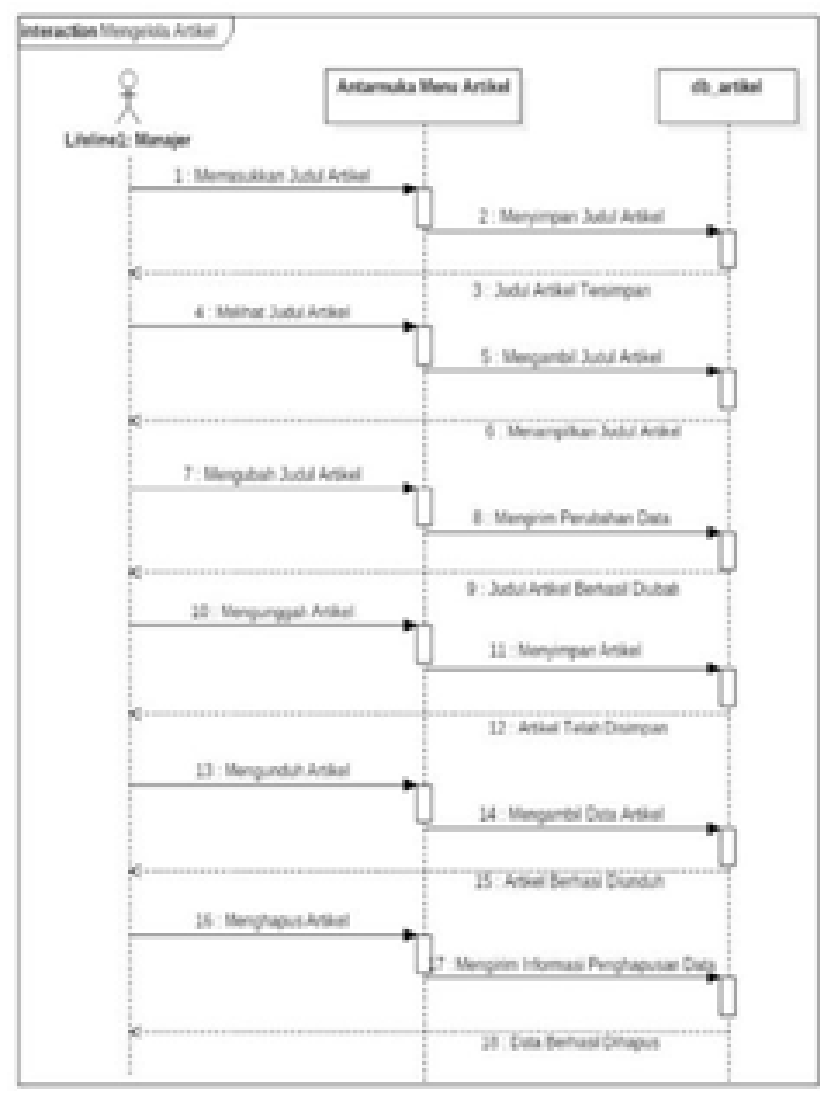

Gambar 21 Sequence Diagram Mengelola Artikel

Gambar 21 menunjukkan urutan dari sistem yang berlangsung ketika manajer telah masuk kedalam sistem. Manajer dapat melakukan beberapa kegiatan seperti melihat judul maka data akan diambil dari tabel artikel. Jika manajer ingin mengubah atau menghapus sebuah artikel maka data yang ada didalam tabel artikel akan dirubah sesuai dengan data yang dimasukkan atau dihapus.

Gambar 22 menunjukkan urutan dari sistem yang telah diakses oleh manajer yang sebelumnya telah masuk kedalam sistem. Manajer dapat melakukan manipulasi data seperti melihat, mengubah, menghapus, mengunggah dan mengunduh undangan. Setiap perubahan data yang terjadi akan disimpan kedalam basis data.

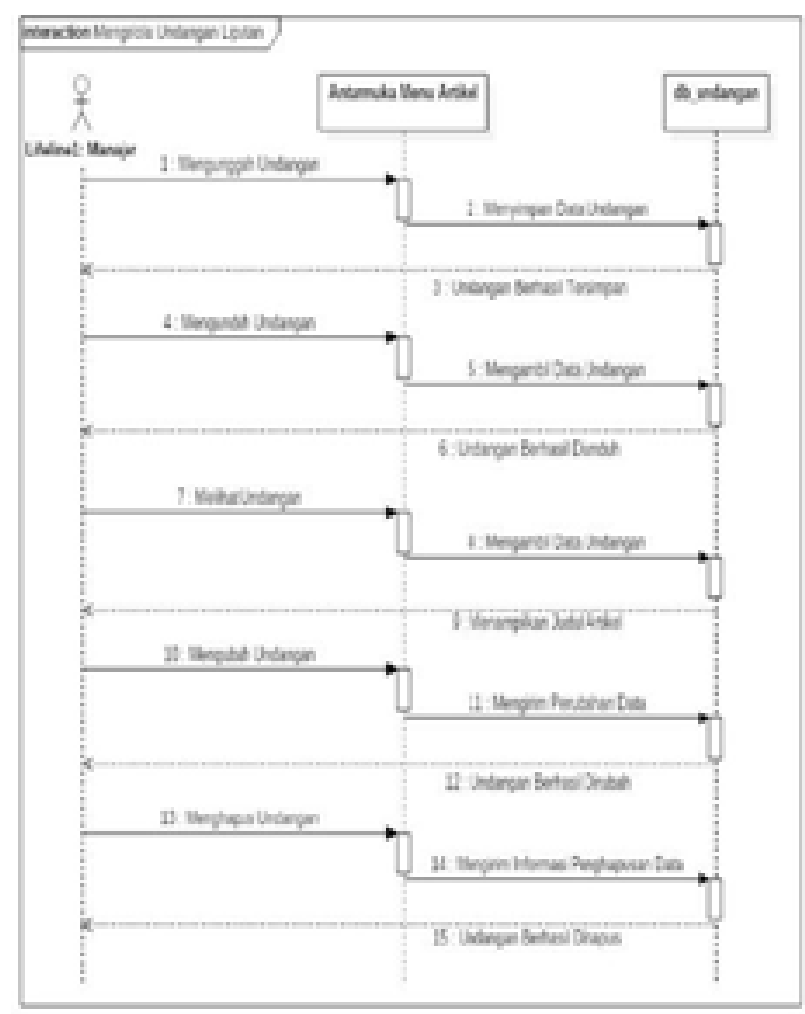

Gambar 22 Sequence diagram mengelola undangan liputan

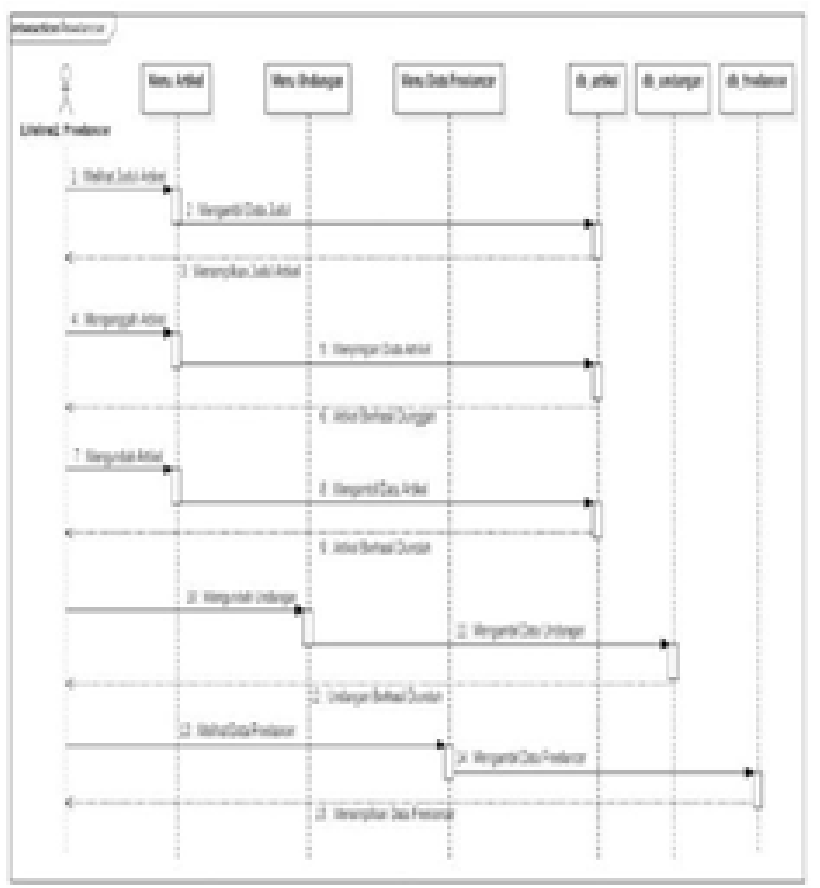

Gambar 23 Sequence diagram mengelola artikel dan undangan liputan

\section{c. Freelancer}

Freelancer memiliki mendeskripsikan waktu hidup antara freelancer, antarmuka dan database yang saling mengirim dan menerima suatu objek.

Gambar 23 menunjukkan proses yang dilakukan oleh admin yang telah berhasil masuk kedalam sistem. Freelancer memiliki hak akses yang terbatas pada database artikel. Maka dari itu, freelancer hanya dapat melakukan beberapa kegiatan seperti melihat 
melihat judul artikel, mengunggah dan mengunduh artikel serta mengunduh undangan. Ketika freelancer mengunduh artikel maka data yang ada pada database artikel dapat ditampilkan dan dapat disimpan oleh freelancer pada komputer.

\section{d. Admin}

Sequence diagram admin mendeskripsikan waktu hidup antara admin, antarmuka dan database yang saling mengirim dan menerima suatu objek.

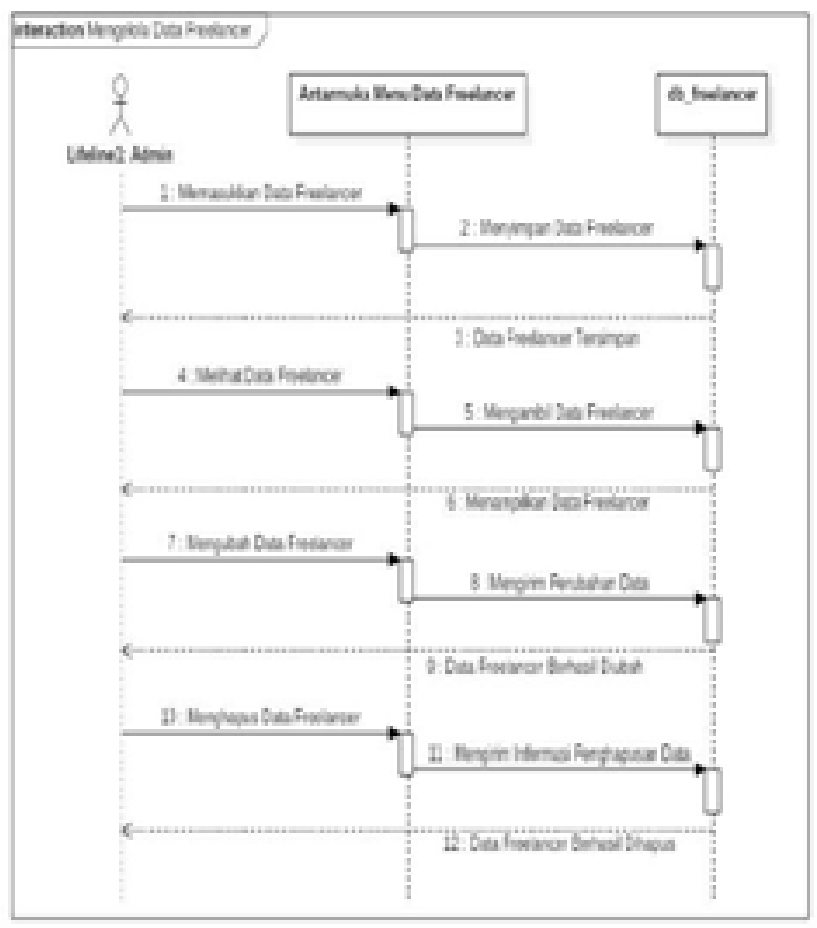

Gambar 24 Sequence diagram mengelola data freelancer

Gambar 24 menunjukkan proses ketika admin telah masuk kedalam sistem. Admin dapat melakukan beberapa kegiatan seperti melihat, memasukkan, mengubah dan menghapus data freelancer. Setiap proses perubahan data yang terjadi maka perubahan data tersebut akan langsung bisa disimpan kedalam basis data.

Pada Gambar 25 menunjukkan bahwa admin dapat mengelola data barang dengan melakukan manipulasi data seperti melihat, memasukkan, mengubah dan menghapus barang. Dengan hak akses yang dimiliki oleh admin, maka setiap data barang yang diperbaharui atau diubah akan langsung diproses dan disimpan kedalam basis data.

\section{e. Keuangan}

Sequence diagram administrator mendeskripsikan waktu hidup antara admin, antarmuka dan database yang saling mengirim dan menerima suatu objek.

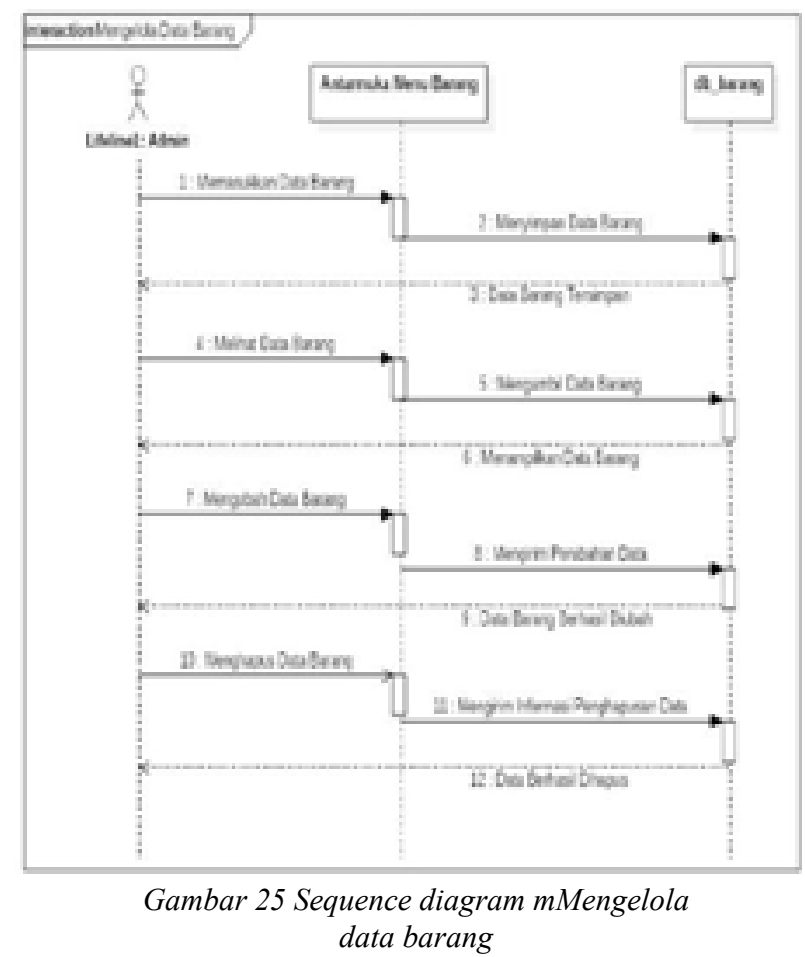

Pada Gambar 26 dapat dilihat bahwa keuangan memiliki peran dalam mengelola gaji freelancer. Dalam mengelola data gaji freelancer, keuangan memiliki hak akses untuk memasukkan, melihat, mengubah dan menghapus data gaji. Database akan menyimpan setiap masukkan data dan perubahan data yang dilakukan oleh keuangan terhadap data gaji freelancer.

\section{F. Perancangan Basis Data}

Berikut merupakan perancangan basis data yang digunakan pada sistem informasi pengelolaan

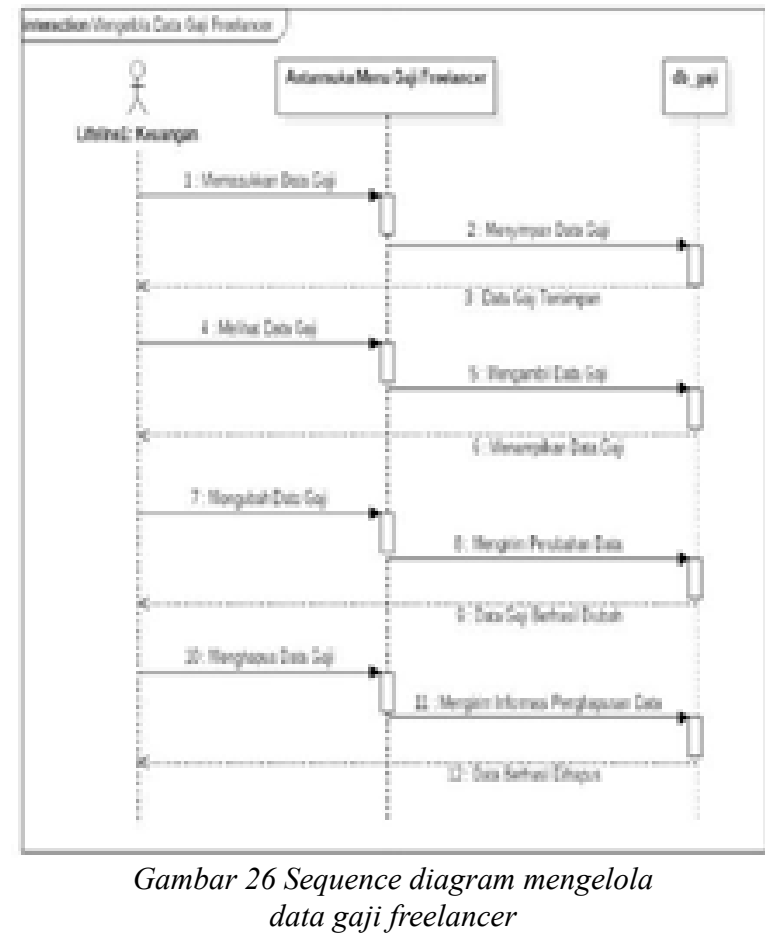


freelancer pada Playcubic. Gambar 27 dan Gambar 28 menjelaskan mengenai perancangan basis data pada sistem usulan yang terdiri dari 6 buah tabel dan masing-masing tabel memiliki relasi.

\section{CDM (Conseptual Data Model)}

Conceptual Data Model (CDM) adalah pemodelan basis data yang berkaitan dengan pandangan pemakai terhadap data yang disimpan dalam basis data [12].

Berdasarkan sistem usulan yang dibuat, penulis menjabarkan konsep basis data yang ada kedalam bentuk CDM yang terdiri dari tabel-tabel yang akan diimplementasi kedalam sistem. CDM akan dijelaskan pada Gambar 27.

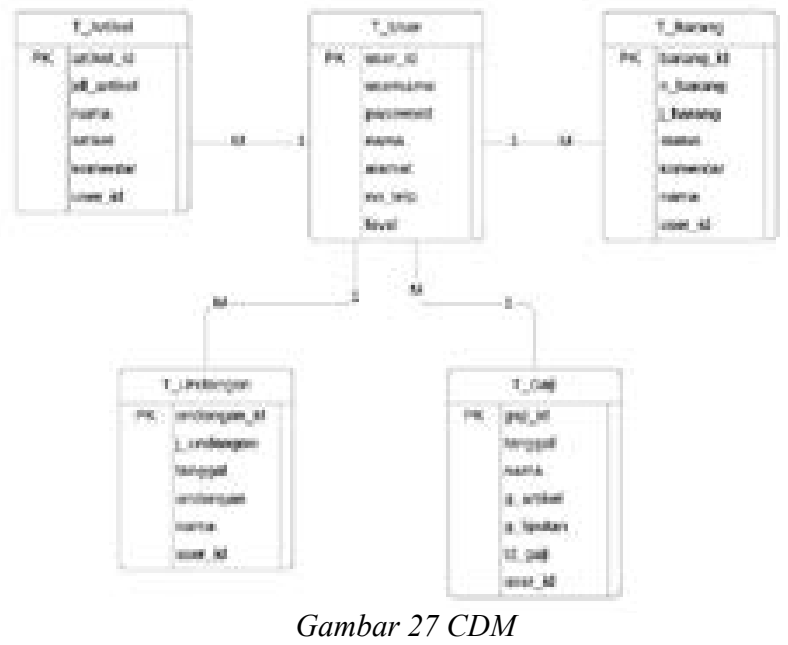

\section{PDM (Physical Data Model)}

Physical Data Model (PDM) adalah model yang menggunakan sejumlah tabel untuk menggambarkan data serta hubungan antara data [13]. PDM menggambarkan proses relasi antar sejumlah tabel yang masing-masing memiliki nama kolom unik dan tipe data. PDM akan dijelaskan pada Gambar 28.

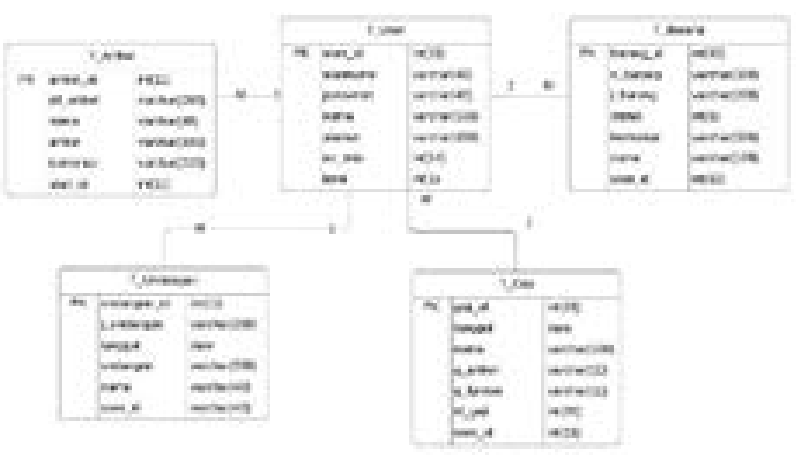

Gambar 28 PDM

\section{G. Perancangan Antar Muka}

Peneliti melakukan pengembangan sistem berdasarkan hasil dari rancangan basis data dan antarmuka sesuai dengan fungsi-fungsi yang terdapat pada perancangan sistem usulan.

\section{Pengguna}

Gambar 29 menjelaskan tampilan login yang memiliki kolom username dan password yang dapat diisi oleh pengguna. Ketika pengguna memasukkan username dan password dengan benar, pengguna dapat langsung mengakses website Playcubic sesuai dengan tampilan menu masing-masing. Apabila pengguna salah memasukkan username atau password, maka pengguna tidak dapat mengakses website Playcubic.

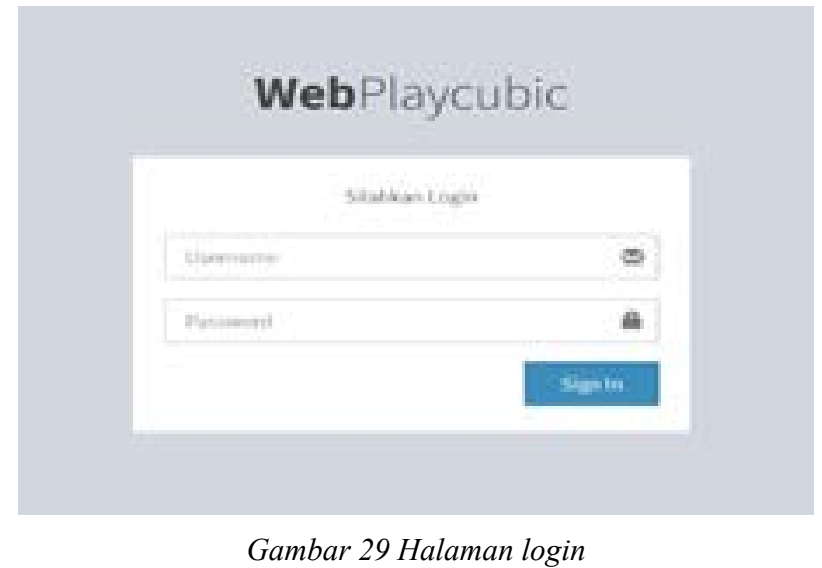

Gambar 30 menjelaskan halaman dashboard yang berisi informasi seperti nama pengguna dan menu yang ditampilkan sesuai dengan pengguna yang masuk kedalam sistem.

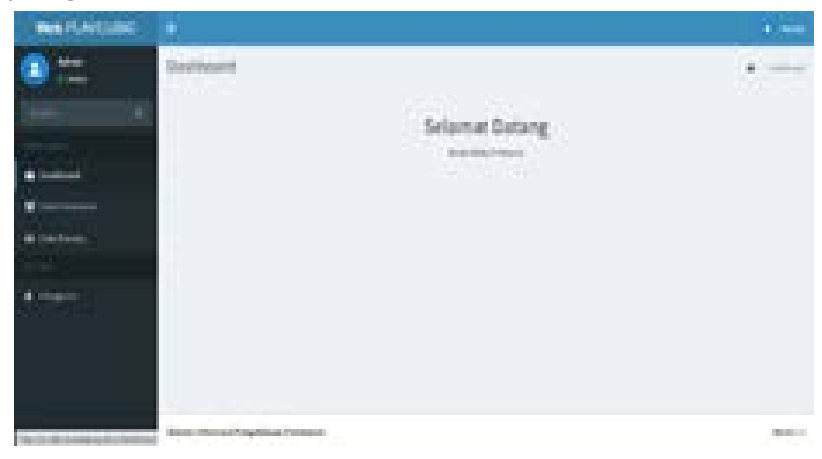

Gambar 30 Halaman dashboard

\section{Admin}

Gambar 31 menjelaskan halaman menu freelancer yang diakses oleh admin. Pada menu ini, admin dapat melihat informasi freelancer.

Gambar 31 menjelaskan halaman data barang yang ditampilkan ketika admin mengakses menu data barang.

Gambar 32 dan Gambar 33 menjelaskan halaman data barang ketika admin melakukan manipulasi data pada menu data barang. Gambar 32 berisi kolom-kolom yang harus diisi apabila admin 


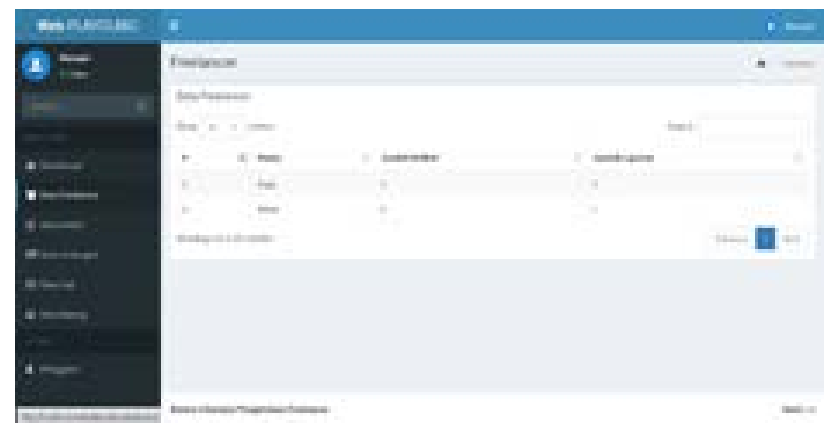

Gambar 31 Halaman freelancer

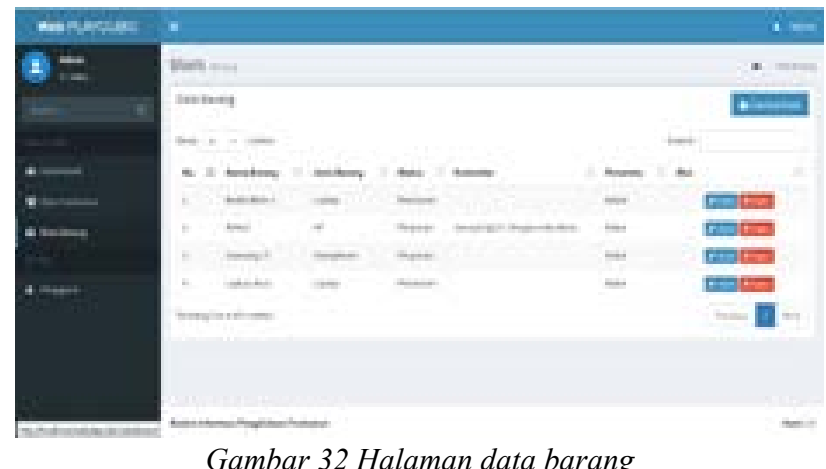

Gambar 32 Halaman data barang

ingin menambahkan data kedalam sistem. Gambar 33 berisikan kolom-kolom yang harus diisi apabila admin ingin melakukan perubahan pada sistem.

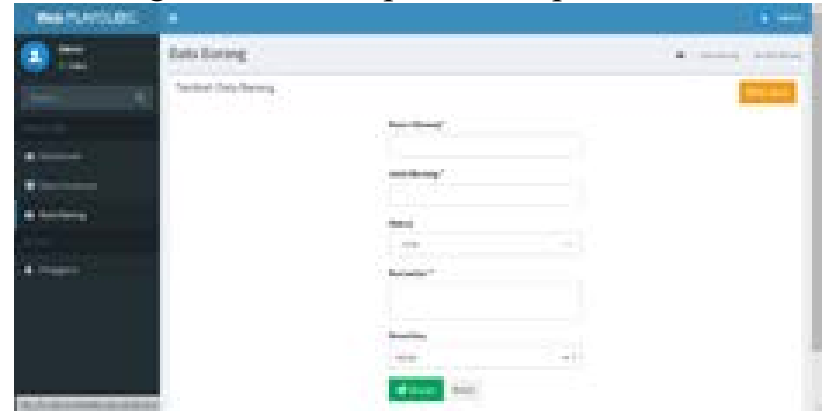

Gambar 33 Halaman tambah barang

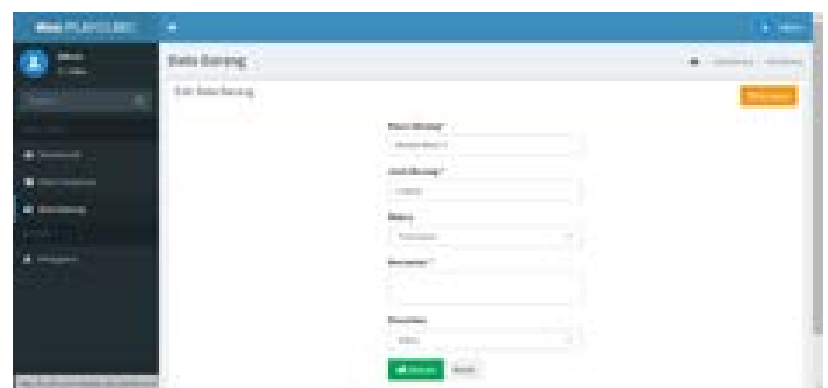

Gambar 34 Halaman ubah data barang

Gambar 34 menjelaskan halaman menu pengguna dimana admin dapat melihat informasi pengguna yang ada di web playcubic. Admin juga memiliki hak akses untuk dapat melakukan manipulasi data seperti menambahkan dan mengubah data pengguna yang ditunjukkan pada Gambar 35 dan Gambar 36.

Gambar 35 menjelaskan halaman tambah data pengguna yang dapat diakses oleh admin. Admin dapat menambahkan data dengan cara memasukkan

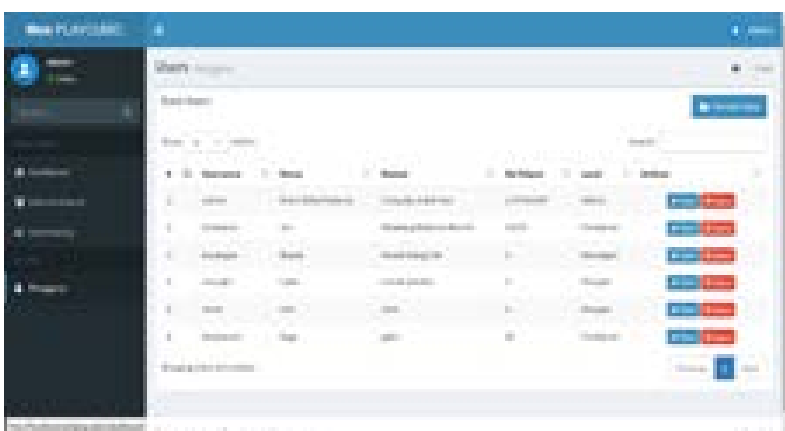

Gambar 35 Halaman pengguna

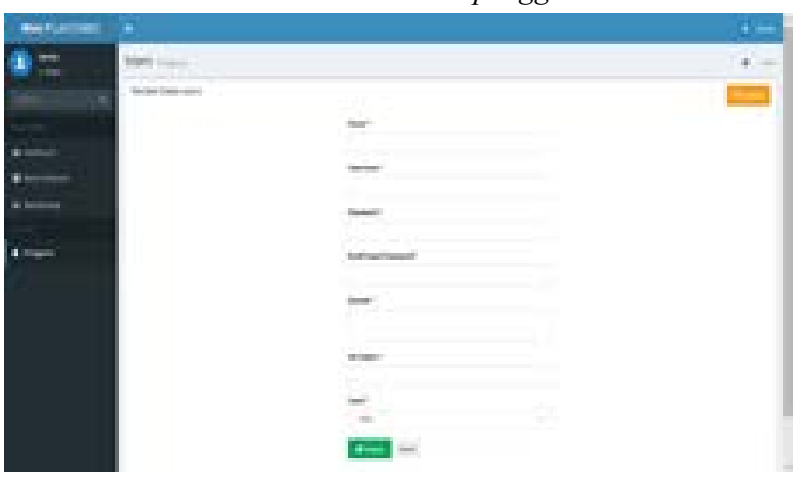

Gambar 36 Halaman tambah pengguna

informasi kedalam kolom-kolom yang tersedia. Admin juga dapat mengubah data dengan cara mengubah data pada kolom yang tersedia pada Gambar 36.

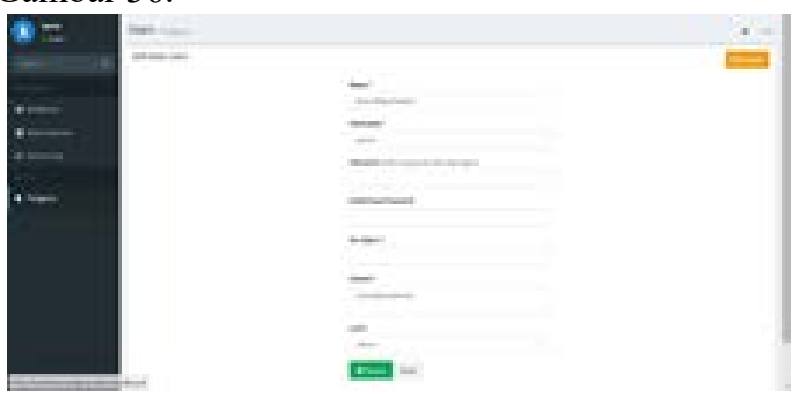

Gambar 36 Halaman ubah data pengguna

\section{Manajer}

Gambar 37 menjelaskan halaman freelancer yang memuat informasi mengenai jumlah artikel dan jumlah undangan yang telah dilakukan oleh freelancer. Manajer memiliki hak akses yakni hanya dapat melihat data freelancer tanpa melakukan aksi yang lainnya.

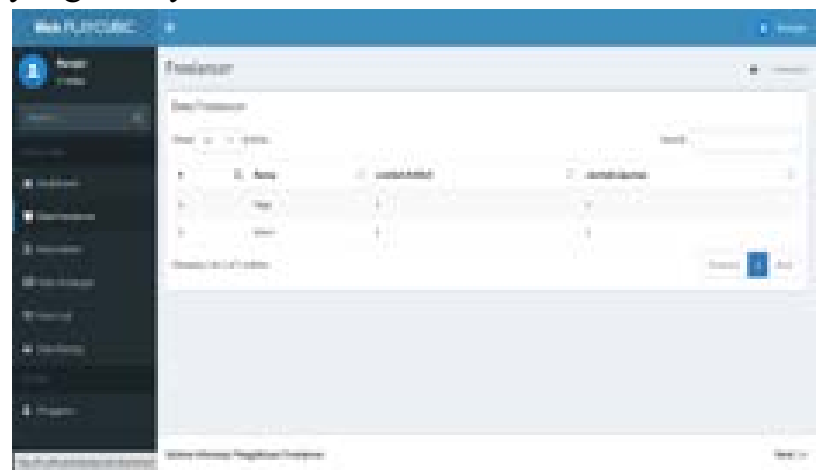

Gambar 37 Halaman data freelancer 
Gambar 38 menjelaskan halaman data artikel yang berisi informasi mengenai artikel beserta nama-nama freelancer yang telah mengerjakan artikel. Manajer dapat melakukan manipulasi data seperti menambahkan, mengubah, mengunduh dan menghapus data artikel.

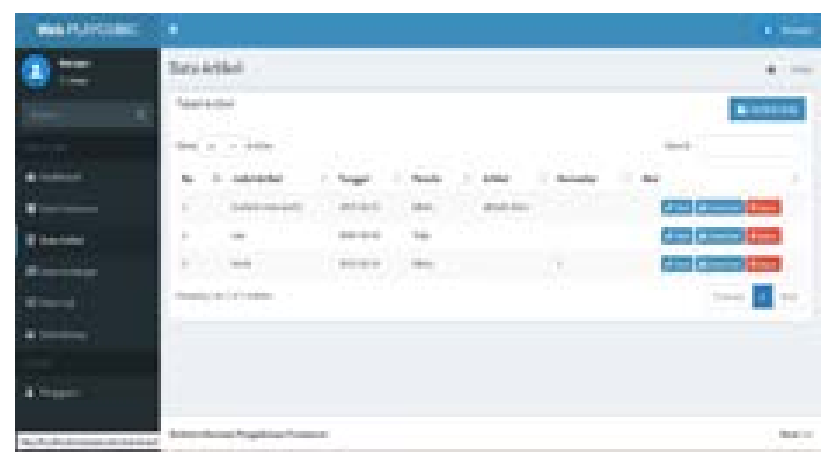

Gambar 38 Halaman Artikel Freelancer

Gambar 39 menjelaskan halaman tambah data artikel yang berisi kolom-kolom yang akan diisi apabila manajer ingin menambah data artikel. Gambar 40 menjelaskan halaman ubah artikel yang berisi kolom-kolom berisi informasi data artikel yang dapat diubah oleh manajer.

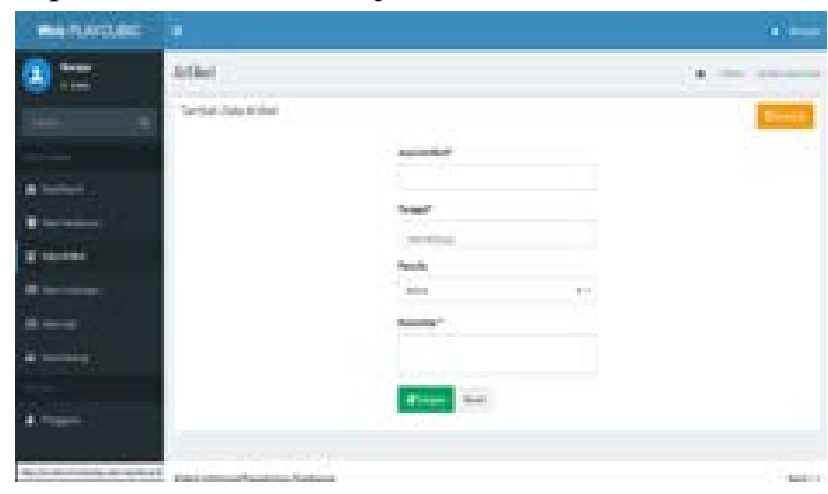

Gambar 39 Halaman Tambah Artikel Freelancer

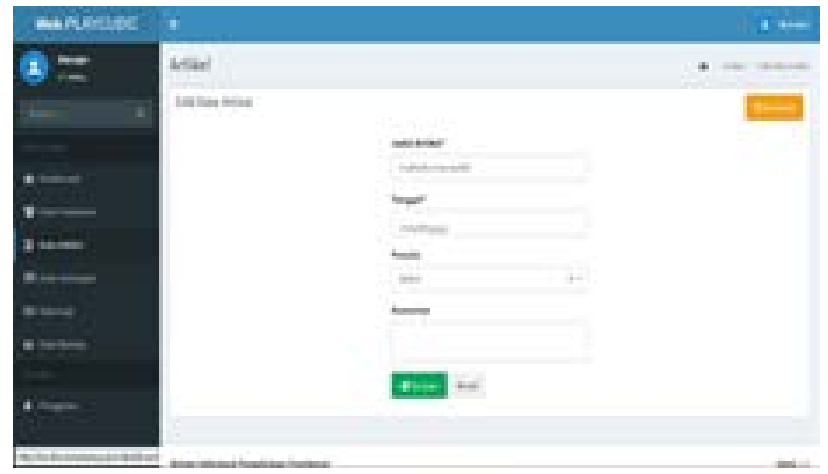

Gambar 40 Halaman Ubah Data Artikel

Gambar 41 menjelaskan halaman data undangan yang dapat dilihat oleh manajer. Pada menu ini, manajer dapat melakukan manipulasi data yang diperlukan menambah, mengubah dan menghapus data undangan.

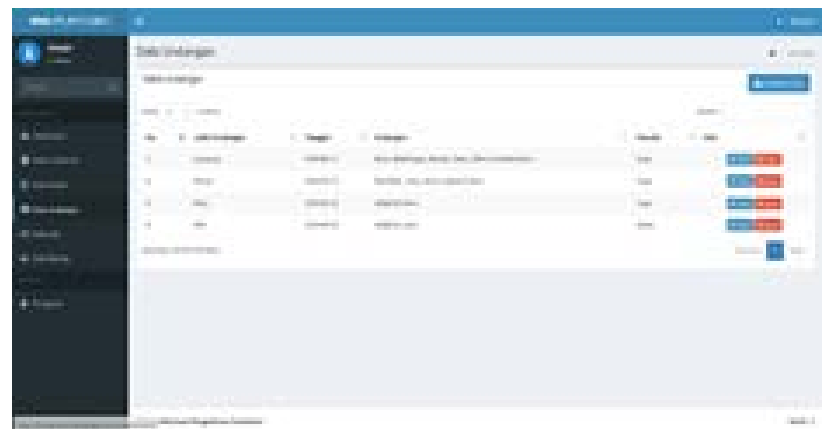

Gambar 41 Halaman data undangan

Gambar 42 menjelaskan halaman menu tambah undangan yang dapat diakses oleh manajer. Manajer dapat menambahkan undangan dan melakukan unggah data dengan cara memasukkan informasi kedalam kolom-kolom yang telah tersedia. Manajer juga dapat mengubah data yang ada pada menu undangan dengan mengubah informasi dalam kolom data undangan yang ditunjukkan pada Gambar 43.

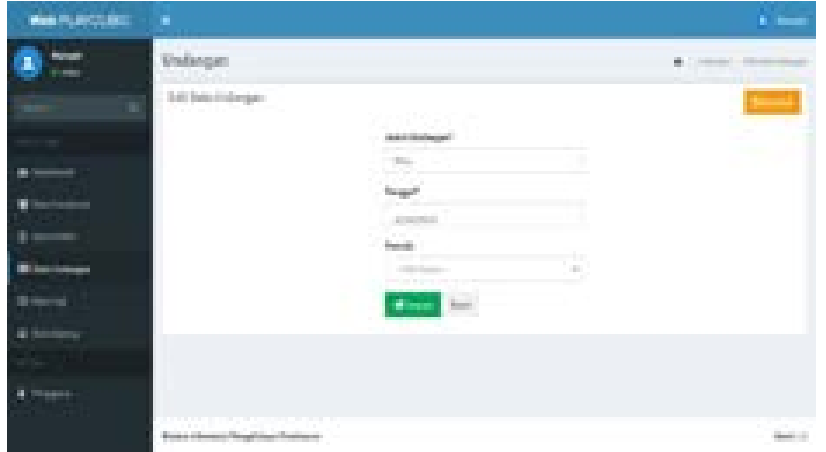

Gambar 42 Halaman unggah undangan

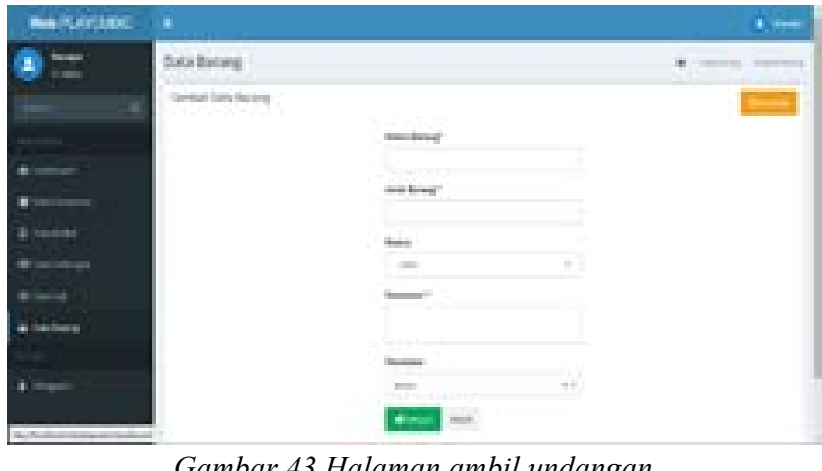

Gambar 44 menjelaskan halaman menu barang yang dapat diakses oleh manajer. Manajer memiliki hak akses untuk dapat melakukan manipulasi data barang seperti menambah, mengubah dan menghapus data barang.

Gambar 45 menunjukkan halaman menu tambah data barang yang dapat diisi oleh manajer untuk menambah data barang kedalam sistem. Gambar 46 menjelaskan halaman data ubah data yang dapat diakses oleh manajer. Manajer dapat mengubah data dengan cara mengubah informasi yang ada dikolom menu ubah data barang. 


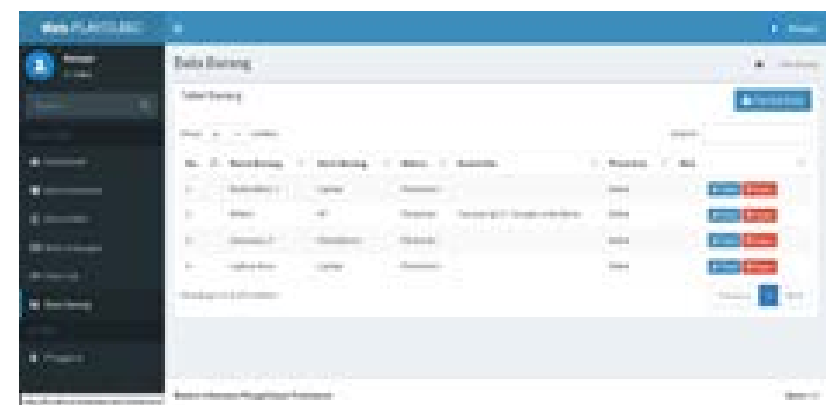

Gambar 44 Halaman data barang

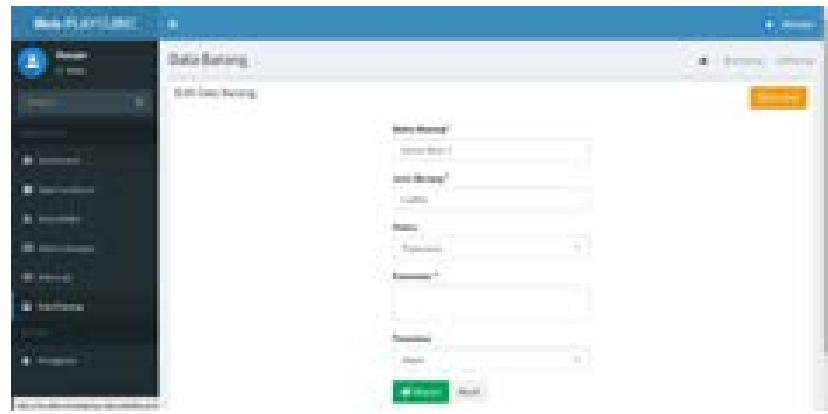

Gambar 45 Halaman tambah barang

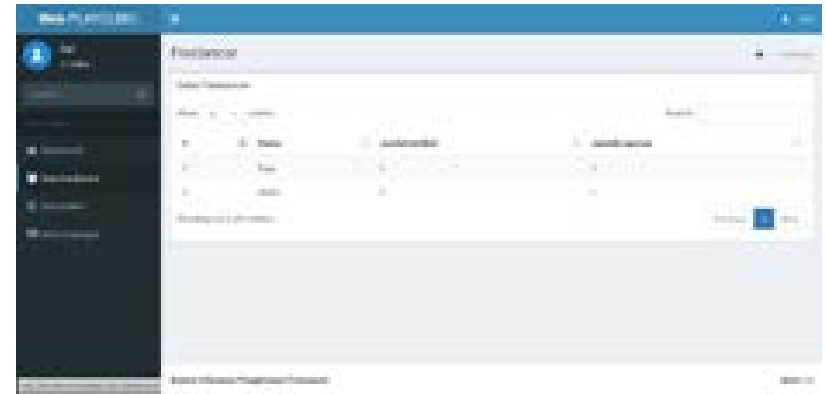

Gambar 46 Halaman ubah data barang

Gambar 47 menunjukkan halaman data pengguna yang dapat diakses dan dilihat oleh manajer. Manajer memiliki batasan yakni hanya dapat melihat data pengguna.

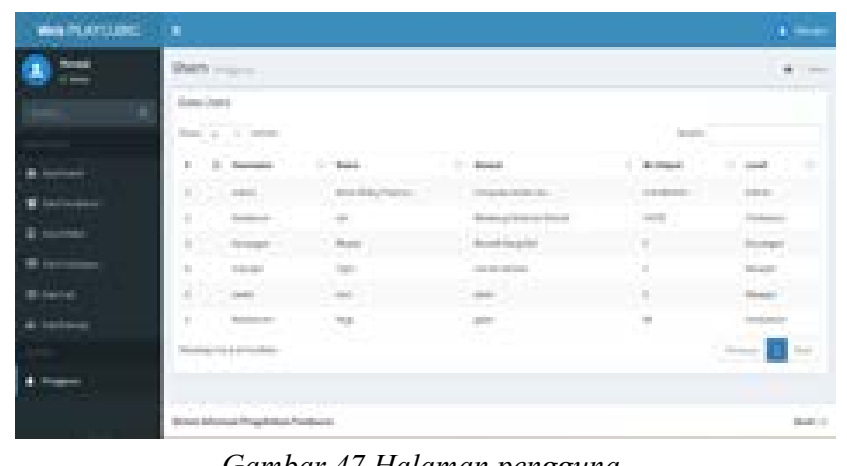

Gambar 47 Halaman pengguna

\section{Freelancer}

Gambar 48 menjelaskan halaman menu freelancer yang dapat diakses oleh freelancer. Pada menu ini, freelancer dapat melihat jumlah artikel dan jumlah liputan yang telah di kerjakan.

Gambar 49 menunjukkan halaman data artikel yang dapat diakses oleh freelancer. Pada menu ini,

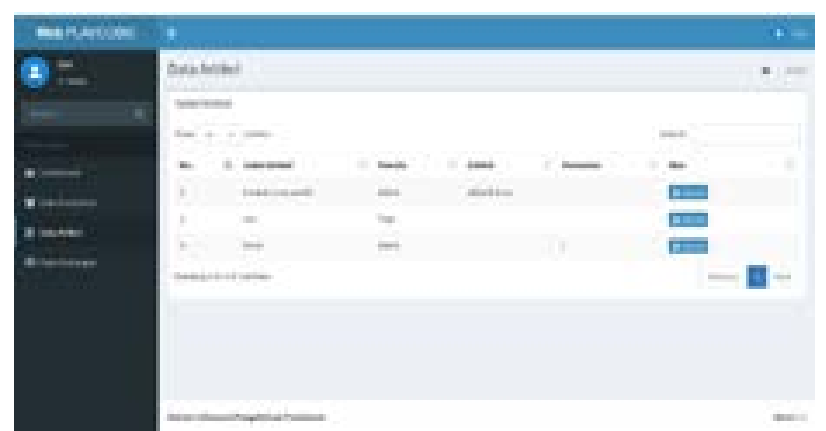

Gambar 48 Halaman menu freelancer

freelancer dapat melihat judul artikel yang akan dikerjakan. Freelancer juga dapat mengunggah artikel yang telah dikerjakan seperti yang ditunjukkan pada Gambar 50

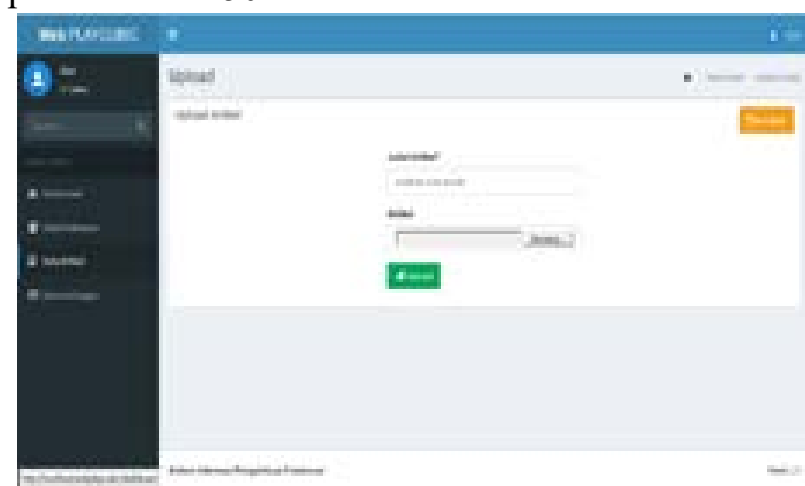

Gambar 49 Halaman menu artikel

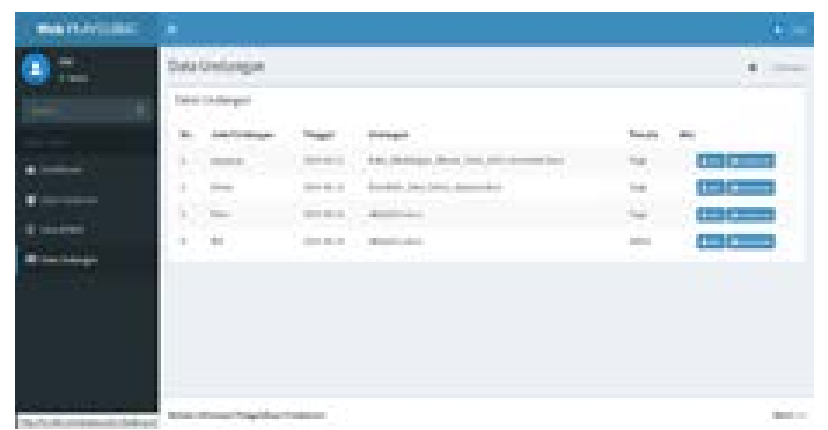

Gambar 50 Halaman unggah artikel

Gambar 51 menunjukkan halaman menu undangan yang dapat diakses oleh freelancer. Freelancer dapat mengunduh undangan dan dapat mengikuti undangan dengan menekan tombol ikut seperti yang ditunjukkan pada Gambar 52

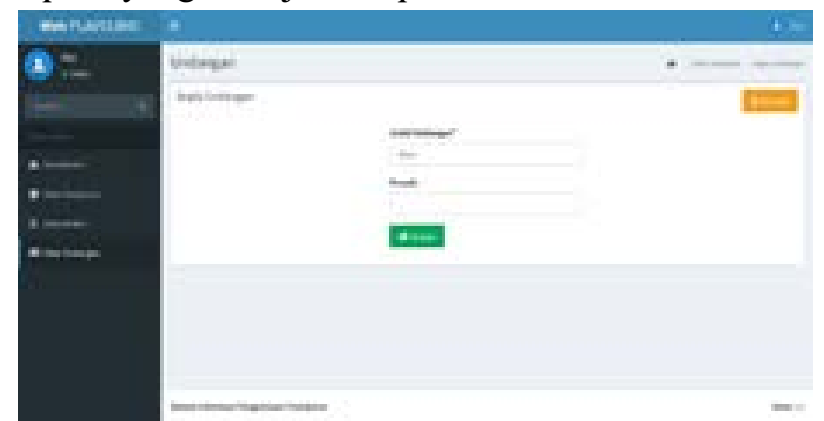

Gambar 51 Halaman menu undangan

\section{Keuangan}

Gambar 53 menunjukkan menu freelancer yang dapat diakses oleh keuangan. Keuangan memiliki hak 
akses untuk melihat freelancer tanpa mampu untuk melakukan manipulasi data.

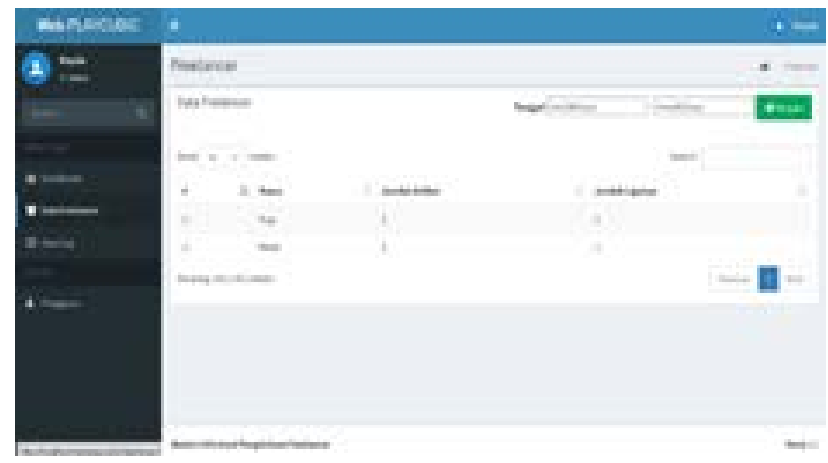

Gambar 53 Halaman Data Freelancer

Gambar 54 menjelaskan halaman menu data gaji freelancer yang dapat diakses oleh keuangan. Pada menu ini, keuangan dapat melakukan manipulasi data seperti menambahkan data seperti pada Gambar 55 dan mengubah data seperti yang ditunjukkan pada Gambar 56.

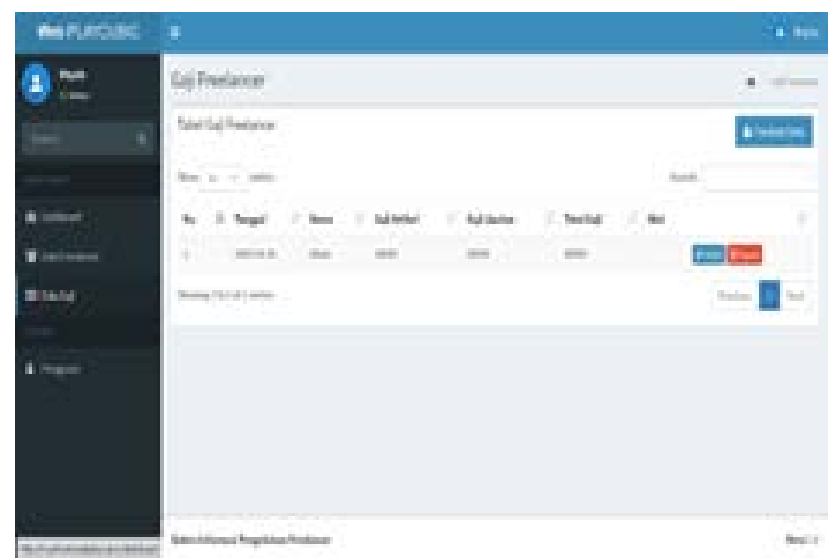

Gambar 54 Halaman Gaji Freelancer

Gambar 56 menunjukkan halaman data pengguna yang dapat diakses oleh keuangan. Keuangan memiliki batasan yakni hanya dapat melihat data pengguna tanpa melakukan manipulasi data lainnya.

\section{H. Pengujian Sistem}

Pada tahap pengujian sistem, penulis menggunakan jenis pengujian blackbox testing

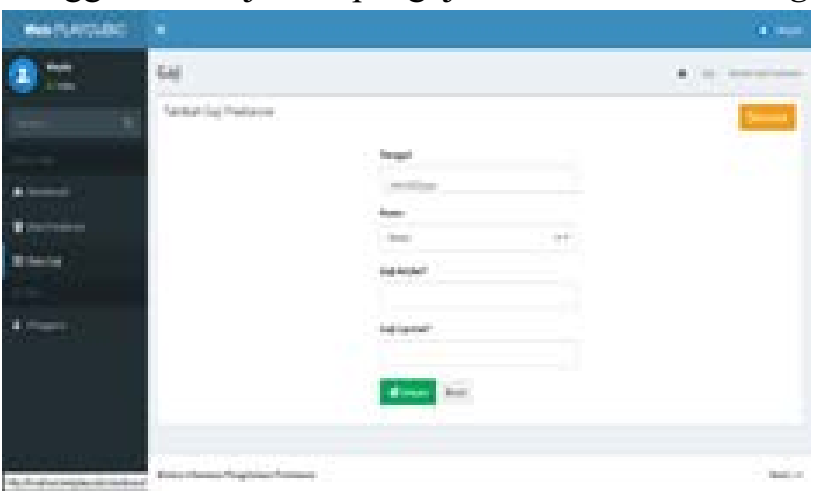

Gambar 55 Halaman Tambah Gaji Freelancer

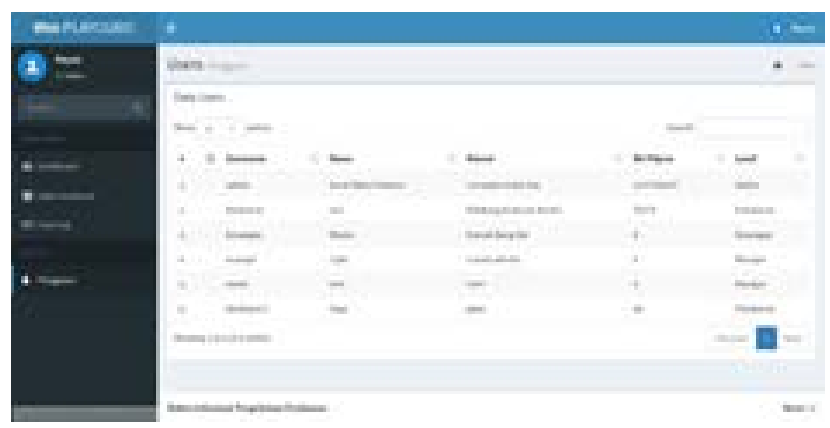

Gambar 56 Halaman pengguna

dengan klasifikasi alpha testing. Black box testing merupakan salah satu metode pengujian sistem yang berfokus pada spesifikasi fungsional pada aplikasi sehingga tester dapat menjelaskan kondisi input serta melakukan pengetesan pada sisi fungsional program [14].

Pengujian Alpha merupakan salah satu strategi pengujian yang merupakan klasifikasi dari black box testing. Pada jenis pengujian ini, pengguna dapat menggunakan aplikasi serta memberikan feedback berupa pengisian kuesioner dan peneliti dapat mengetahui setiap masukan dan perilaku yang tidak normal pada sistem. Lalu peneliti dapat melakukan perbaikan dari hasil kuesioner yang diberikan [15].

Pengujian ini dilakukan untuk menguji sistem pengelolaan freelancer Playcubic. Pengujian yang dilakukan peneliti pada Sistem Informasi Pengelolaan Freelancer Berbasis Web pada Playcubic menggunakan metode black box testing. Dalam pengujian black box testing, dilakukan pada para pengguna meliputi manajer, freelancer, admin dan keuangan pada fungsi setiap menu yang ada. Pengujian ini dilakukan peneliti untuk mengevaluasi sistem yang telah dibangun sehingga sesuai dengan harapan dan kebutuhan fungsional yang ingin dicapai.

Hasil pengujian yang diperoleh oleh peneliti yang menggunakan metode pengujian black box testing dan klasifikasi alpha testing pada Sistem Informasi Pengelolaan Freelancer Berbasis Web pada Playcubic telah diuji dan mendapatkan hasil bahwa sistem tersebut sesuai dengan rancangan awal dan telah berjalan dengan baik. Sehingga dapat disimpulkan bahwa sistem tersebut sudah dapat digunakan oleh pihak Playcubic.

\section{SIMPULAN}

Sistem Informasi Pengelolaan Freelancer Pada Playcubic Berbasis Web merupakan sistem informasi yang dibangun untuk membantu mengelola freelancer meliputi pembagian judul artikel, liputan, penggajian, inventori dan data freelancer Playcubic. Dalam membangun sistem informasi 
ini, peneliti menggunakan bahasa pemrograman PHP yang dijalankan pada perangkat lunak sublime text serta XAMPP sebagai web server lokal yang dapat mengkoneksikan program PHP pada basis data MySQL. Dengan menggunakan metode pengembangan sistem prototype, peneliti mengawali pembangunan sistem dimulai dari proses pengumpulan data berupa wawancara dan observasi langsung yang dilanjutkan dengan studi literatur, analisis masalah, perancangan sistem, pengembangan sistem dan pengujian sistem. UML (Unified Modelling System) digunakan sebagai alat bantu untuk memberikan visualisasi akan sistem yang sedang dibangun kepada pemilik Playcubic. Proses pengujian sistem berjenis blackbox testing dengan klasifikasi alpha testing digunakan untuk menguji kemampuan sistem agar sesuai dengan fungsi awal yang telah didiskusikan dengan Bapak Romi Sugara selaku pemilik Playcubic.

\section{DAFTAR RUJUKAN}

[1]. N. Fadilla, "Unsur Layak Berita Pada Produk Jurnalistik Rubrik Infotainment di Media Online,” p. 7, 2017.

[2]. Mustofa, "Pengertian Freelance," Pekerja Lepas (Freelancer) Dalam Dunia Bisnis, vol. 10, p. 22, 2018.

[3]. D. Puspitasari, "Rancang Bangun Sistem Informasi Koperasi Simpan Pinjam Karyawan Berbasis Web," Jurnal Piral Nusa Mandiri, vol. 11, p. 186, 2015.

[4]. Y. Elva, "Perancangan sistem Informasi Kepegawaian Berbasis WEB Pada Badan Kepegawaian Daerah (BKD) Dengan Menggunakan Bahasa Scripting PHP dan Database MySQL,” Jurnal Teknologi, vol. 6, pp. 20-26, 2016.
[5]. E. Y. Anggraeni and R. Irviani, in Pengantar SIstem Informasi, Yogyakarta, CV. Andi Offset, 2017.

[6]. H. T. Sitohang, "Sistem Informasi Pengagendaan Surat Berbasis Web Pada Pengadilan Tinggi Medan,” Journal of Informatic Pelita Nusantara, vol. 3, p. 7, 2018.

[7]M. Shalahuddin and R. A. Sukamto, Rekayasa Perangkat Lunak Terstruktur dan Berorientasi Objek, Bandung: Informatika Bandung, 2015.

[8]. M. Shalahuddin and R. A. Sukamto, Rekayasa Perangkat Lunak Terstruktur dan Berorientasi Objek, Bandung: Informatika Bandung, 2015.

[9]. M. Shalahuddin and R. A. Sukamto, Rekayasa Perangkat Lunak Terstruktur dan Berorientasi Objek, Bandung: Informatika Bandung, 2015.

[10]. M. Shalahuddin and R. A. Sukamto, Rekayasa Perangkat Lunak Terstruktur dan Berorientasi Objek, Bandung: Informatika Bandung, 2015.

[11]. M. Shalahuddin and R. A. Sukamto, Rekayasa Perangkat Lunak Terstruktur dan Berorientasi Objek, Bandung: Informatika Bandung, 2015.

[12]. M. Shalahuddin and R. A. Sukamto, Rekayasa Perangkat Lunak Terstruktur dan Berorientasi Objek, Bandung: Informatika Bandung, 2015.

[13]. M. Shalahuddin and R. A. Sukamto, Rekayasa Perangkat Lunak Terstruktur dan Berorientasi Objek, Bandung: Informatika Bandung, 2015.

[14]. M. S. Mustaqbal, R. F. Firdaus and H. Rahmadi, "Pengujian Aplikasi Menggunakan Black Box Testing Boundary Value Analysis," Jurnal Ilmiah Teknologi Informasi Terapan, vol. 1, p. 33, 2015.

[15]. J. Simarmata, "Pengujian Alfa (alpha testing)," in Rekayasa Perangkat Lunak, Yogyakarta, ANDI Yogyakarta, 2009, p. 321. 